Article

\title{
How to Communicate Sustainability: From the Corporate Web to E-Commerce. The Case of the Fashion Industry
}

\author{
Patricia SanMiguel $^{1, *(\mathbb{D})}$, Silvia Pérez-Bou $\left.{ }^{2,+} \mathbb{(}\right)$, Teresa Sádaba ${ }^{1}\left(\mathbb{D}\right.$ and Pedro Mir-Bernal ${ }^{1}$ \\ 1 Department of Marketing, ISEM Fashion Business School, University of Navarre, 28027 Madrid, Spain; \\ teresa.sadaba@isem.es (T.S.); pmir@unav.es (P.M.-B.) \\ 2 Department of Theory, Projects and Urbanism, School of Architecture, University of Navarre, \\ 31009 Pamplona, Spain; sperezb@unav.es \\ * Correspondence: patricia.sanmiguel@isem.es \\ + Part of the research was carried out during a stay as a Visiting Scholar at the Department of Textile \\ Engineering of the School of Engineering, University of Minho, Guimaraes, Portugal.
}

Citation: SanMiguel, P.;

Pérez-Bou, S.; Sádaba, T.;

Mir-Bernal, P. How to Communicate Sustainability: From the Corporate Web to E-Commerce. The Case of the Fashion Industry. Sustainability 2021, 13, 11363. https://doi.org/ $10.3390 /$ su132011363

Academic Editor: Marc Lim

Received: 31 August 2021

Accepted: 6 October 2021

Published: 14 October 2021

Publisher's Note: MDPI stays neutral with regard to jurisdictional claims in published maps and institutional affiliations.

Copyright: (C) 2021 by the authors Licensee MDPI, Basel, Switzerland. This article is an open access article distributed under the terms and conditions of the Creative Commons Attribution (CC BY) license (https:// creativecommons.org/licenses/by/ $4.0 /)$.

\begin{abstract}
Sustainability strategy at companies has become a key business and management aspect for the development and success of an enterprise. The communication of strategies and actions relating to sustainability has become increasingly important for both companies and brands. This research studies the communication process that forms part of the sustainable strategy of fashion companies, ranging from the corporate website to e-commerce, and it proposes improvements for sustainability communication. Two new models are presented: the Operational Model for Evaluating Fashion Corporate Websites (OMEFCW) and the Operational Model for Evaluating Fashion E-Commerce (OMEFeC), based on the core dimensions of online sustainability communication (orientation, structure, ergonomics and content-OSEC), as established by Siano. In order to obtain an optimal view of the fashion industry, four corporate groups-two luxury fashion groups (Kering Group and Moët Hennessy Louis Vuitton (LVMH)) and two fast fashion groups (H\&M Group and Intidex)-are compared. In addition, all of the e-commerce operations of the groups' fashion brands are analyzed, a total of 32 brands. The results show that it is necessary to continue improving in terms of the communication of sustainability within the fashion industry, whilst demonstrating the great deficiency that exists regarding the communication of sustainability in the case of the brands' e-commerce operations, which are precisely the web pages most visited by consumers.
\end{abstract}

Keywords: communication of sustainability; sustainability; marketing management; corporate website; e-commerce; fashion; fast fashion; luxury fashion

\section{Introduction}

The sustainability strategy at companies has become an essential part of the vision and mission of a company given that sustainability is a key business and management aspect for the development and success of any enterprise [1,2].

Various studies analyze the importance of communicating companies' sustainability strategy to the different stakeholders that make up a company [1,3-6]. Most of these studies have focused on the communication of sustainability from a corporate point of view, but very few studies analyze how the sustainable strategy is communicated to the consumer. In fact, studies that analyze this aspect are almost non-existent, taking into account the possible effects of the COVID-19 pandemic and the development of commercial websites over the last five years.

This research aims to study the communication process relating to the sustainable strategy at companies, ranging from the corporate website to e-commerce, in order to propose improvements for communication relating to sustainability, a business dimension that has become increasingly important in the eyes of society [7-9]. 
This study analyzes the corporate websites of the H\&M and Inditex fast fashion business groups, and the Kering and Moët Hennessy Louis Vuitton (LVMH) luxury fashion groups. Each group has multiple brands that have commercial websites that offer the possibility of online shopping, e-commerce. For this study, we have analyzed all the e-commerce operations of the brands relating to clothing and accessories, without taking into account other product categories (jewelry, home textiles, perfumes and cosmetics, wines, etc.).

This comparison of the communication strategies relating to sustainability at fast fashion and luxury fashion companies allows us to highlight the best communication practices for sustainability within this creative industry, these being management aspects that should be imitated.

Fashion is considered to be a creative industry, not only due to the large number of creative professionals working in its value chain (designers, artistic directors, photographers, illustrators, media creators, advertisers, etc.), and its product chain-fashion garments-that are sometimes even considered works of art [10], but also due to the way in which fashion companies interact with their consumers and even with the cities where they are based, helping them to be seen as "creative" too [11].

The main objective of this paper is to address the potential discrepancy that exists between what companies communicate through the corporate web and what they communicate to consumers. Communication to the consumer regarding the company's sustainability strategy in e-commerce allows the consumer to be made aware of the impact of fashion production on the planet, workers and consumers [2].

Section 2 offers a review of the literature on sustainable development management strategy in the fashion industry and the most prominent literature on how to communicate sustainability online through the corporate website and e-commerce. Then, in Section 3, the research methodology and sample are described, in which a new model of analysis for the communication of sustainability is proposed for corporate websites and e-commerce. Section 4 presents the results and a discussion of the $36 \mathrm{web}$ pages analyzed from a quantitative and qualitative perspective, based on a comparative analysis. Section 5 offers a series of conclusions, managerial implications, limitations and suggestions for future studies.

\section{Literature Review}

\subsection{Fashion as a Creative Industry}

The fashion industry has all the aspects that derive from its creative nature (rapidity, art, color, shapes, patterns, visual design, photography, intellectual property, storytelling, designers, shows, catwalks, etc.), and all the constraints and potential of a big industry, with its value chain being both complex and multileveled.

Creative industries are those "that have their origin in individual creativity, skill and talent, and which have a potential for wealth and job creation through the generation and exploitation of intellectual property", to cite a definition from the 1990s coined by the UK Department of Media, Culture and Sports. They are also "those which are professionally involved in the process of creation, production, and distribution of creative goods and services" [12].

Some scholars who write about fashion as a creative industry declare that these are companies where creativity is the core business [13]. Others reinforce the idea that they draw upon creativity and talent, resources that all countries are richly endowed with [12] Casadei and Lee [11] argue that the fashion industries are one of the exemplary creative industries, and they help cities to be seen as "creative" too.

At Bauhaus, the pioneering center for design and architecture created in Weimar in 1919 , there was a weaving workshop. This center sought to become a focus of creativity, art and craftsmanship, featuring an innovative pedagogical concept based on "form follows function", and summarized in the famous phrase coined by its first director, Walter Gropius: "Art and Technology: A New Unity". The weaving and textiles workshop was one of the most successful workshops at Bauhaus. It was there that many leaders of international textile design were trained, following two different design approaches: one more artistic 
and creative, and the other more industrial [14]. One hundred years later, the fashion and textile industry continues to include both pathways: creative and artistic, and industrial and technical.

That is why The New European Bauhaus, a creative and interdisciplinary project launched by the European Commission in 2021, did not hesitate to include fashion as a key player for the current transition, given that design needs to blend with sustainability. This initiative is a part of the action plan for a greener and more competitive Europe, as outlined in the European Green Deal [15], that also includes "textiles and clothing" as one of the seven key value chains to promote a circular economy.

In the words of Ursula von der Leyen [16], President of the European Commission, in the video presentation for the launch of the design phase of the project, The New Bauhaus is about empowering those who have solutions for the climate crisis; it is about matching sustainability with style; it is a project shaped by all of us, ranging from professional architects to citizen initiatives, from CEOs at big companies to innovative start-ups; and, among other aspects, it is about how to place design at the service of climate solutions.

Its three-word motto, "beautiful, sustainable, together", attracted many fashionorientated projects to the first call for awards in April 2021, among the more than 2000 projects presented.

If we look at the more industrial side of the fashion business, before the COVID-19 pandemic, the industry was estimated to have a market valued at USD 1.8-2.4 trillion [17,18], effectively playing an important role in the world economy by contributing $2-2.5 \%$ to the global GDP [19].

The industry employs around 300 million people worldwide $[17,20]$ as part of a complex and globalized value chain, with the main suppliers and manufacturers being located in Asia (China, India, Bangladesh, Cambodia, Sri Lanka, Vietnam, etc.) and other countries worldwide, mainly developing countries where the salaries are the lowest $[21,22]$, although also some developed countries.

The COVID-19 pandemic has had a dramatic impact, mainly in terms of the loss of millions of human lives, a tragedy caused, in many cases, by poverty. The fashion industry has suffered temporary closures of its stores during the months in which a lockdown was introduced all around the world. The value chain has been disrupted and demand has diminished. Although in 2020 fashion companies suffered a setback of $90 \%$ in terms of financial profit [23], the envisaged scenarios for 2021 are between $0 \%$ and $15 \%$ of sales growth decline compared to 2019, and only in 2023 will the figure revert to 2019 levels. According to Statista 2021, the market decreased in 2020 to USD 1.4 trillion, although it is expected to reach USD 2.2 trillion by 2025, growing 22\% compared to the market of 2019.

\subsection{Fashion and Sustainability}

In our opinion, the best definitions of sustainability are those from the Brundtland Commission [24], namely "development that meets the needs of the present generation without compromising the ability of future generations to meet their own needs", and the triple bottom line described by Elkington that takes into account the social, economic and environmental aspects on an equal basis [25] (p. 51).

After digitalization, sustainability is what fashion executives cite in 2021 as an area of growth, and despite the pandemic, both trends will accelerate and lead to a reset of the fashion industry [23], helping us to navigate uncertainties and allowing companies to turn potential financial, social and environmental threats into opportunities [26]. In addition, creative enterprises are increasingly being viewed as not only new tools for sustainable development [12], but key tools in terms of achieving it [27] since they bring together activities whose raw materials are based on non-natural resources: intangible resources.

However, although fashion as a creative industry uses all kinds of intangible resources, it also consumes a huge quantity of tangible resources, being considered one of the most polluting industries [28]. It is responsible for $8-10 \%$ of the world's greenhouse gas emissions due to its long supply chain [29], which is more than the emissions of all international 
flights and maritime shipping combined [20]. It accounts for $20 \%$ of global wastewater, and it is also a contributor to plastic entering the ocean, as well as chemical and hazardous substances in rivers, etc. Textile production nearly doubled between 2000 and 2019, from 60 million meters to 111 million meters [30].

Viewing the industry from the consumer side, more than $66 \%$ of consumers surveyed in May 2020 by McKinsey stated that brands' promotion of sustainability was an important factor in their purchasing decisions [23].

Both producers and consumers are encouraged to take action to achieve the Sustainable Development Goal 12 (SDG12), fostering more responsible patterns of production and consumption. Clothing utilization decreased by $36 \%$ in the period between 2000 and 2015 [20] and consumption increased from $7 \mathrm{~kg}$ to $13 \mathrm{~kg}$ per person. In order to gain an idea of what this means, the annual environmental impact of a household's clothing in the U.S.A. is equivalent to the waste needed to fill 1000 bathtubs and the carbon emissions from driving an average modern car for 6,000 miles [31].

However, companies have not usually paid enough attention to their consumers as stakeholders [32], and this limits the efficiency and also the effectiveness of actions taken regarding sustainability [33]. Apart from the degree of overconsumption mentioned above, this necessarily implies modifying consumers' habits if we are to tackle this problem. However, there is a lack of involvement with regard to consumers on the part of companies, together with a lack of true and valuable consumer knowledge regarding sustainability. Although some studies have identified the need to educate consumers about the environmental impact of materials and processes [34] and the clothing usage phase [35], other studies have highlighted the fact that if consumers possess knowledge, their awareness rises, and this could trigger a positive attitude towards sustainable products $[32,36]$. Such studies have also suggested that when consumers are familiar with brands and follow them on Twitter, they expect an increasing commitment regarding the environment [37].

All of these factors lead us to formulate our first research hypothesis: H1. In the 2020s, sustainability has become a key business factor regarding the success of fashion companies.

\section{Fast Fashion versus Luxury Fashion}

Sustainable fashion studies have generally focused on luxury fashion and fast fashion brands [38]. According to Pencarelli [39], luxury products are usually those that have the highest price and quality, providing the consumer with an outstanding experience or sense of prestige. Fast fashion has been defined as a business model that combines three elements: (i) quick response; (ii) frequent assortment changes; and (iii) fashionable designs at affordable prices [40].

Some studies analyze the relationship/compatibility between luxury fashion and sustainability [39]. While the vast majority argue that luxury fashion companies should be considered sustainable per se [41-43], and they have less need for sustainability because they are always representative of slow fashion [38], some people consider luxury fashion and sustainability to be irreconcilable by definition, since luxury implies excess, not to mention production and consumption driven by aspects other than satisfying basic needs [42].

There are also scholars that claim that sustainability is more congruent with nonluxury brands because fast fashion production has a serious economic impact $[38,44]$, and because luxury brands are somewhat dissonant when it comes to eco-friendliness.

However, according to Fletcher [45], within the context of slow culture, fast and slow are not opposed: "Slow culture is an invitation to think about systems change in the fashion sector and to question the role of economic growth, underlying values and worldviews in fashion so that a different and truly 'richer' society develops" (p. 264). Some years later, Henninger et al. [46] identified slow fashion with sustainable fashion, since they share many of the same characteristics, such as a balanced approach to fashion production (which fosters long-term relationships), empowering workers throughout the value chain, 
use of upcycling and recycling, and incorporating renewable and organic raw materials, to cite only a few.

A recent experimental study [38] with around 800 German and Korean consumers highlighted the fact that luxury brands can sometimes damage brand attitudes when they advertise economic sustainability; what is more, communication regarding sustainability creates dissonant and conflicting associations for luxury brands because luxury tends to be connected with quality, prestige, exclusivity and uniqueness. Surprisingly, consumers do not identify these characteristics as being sustainable attributes. This is coherent with previous research carried out in 2013 that suggested that sustainability communication in such cases is considered to be a commercial strategy designed to boost sales and it threatens quality and scarcity [47]. In addition, what is not appreciated in the luxury realm is accepted among non-luxury brands since they are best able to leverage cultural and environmental sustainability to increase purchasing intention, according to Kong et al. [38].

Conversely, other scholars [37] have conducted social network analysis and found that brand image is positively influenced by eco-friendly perception, increasing its effect for luxury brands.

The same disparity found amongst consumers can be observed amongst researchers: this is one of the reasons why we wish to address this question in our study. Many authors are skeptical regarding the sustainability efforts of the major fashion retailers $[41,43,48]$. Fletcher [45] questions the model of continuous growth itself, calling for a vision of the fashion sector based on a different starting point.

Based on these findings, we can state our second research hypothesis: H2. Both luxury and fast fashion brands are equally interested in the communication of sustainability.

Continuing with our literature review on sustainability, a great deal has been written regarding all of the aspects of the value chain, mainly upstream (raw materials, products and processes). Luján-Ornelas et al. [22] offer us a literature review based on the different aspects of sustainability at each stage: fiber production (environmental and social impacts of cotton, polyester, lyocell, new and more sustainable fibers, etc.) [49]; textile production, paying attention to processes, energy consumption, chemical treatments, etc.; design; clothing production more focused on social problems, such as low wages [21], safety and technology; commercialization, featuring new business models based on rental schemes and second-hand clothing; subscription services; and, finally, clothing use and end-of-life phases [50,51]. There is also an increasing interest in studying the sustainability of fashion downstream, regarding consumer behavior and the gap between attitudes and purchasing decisions [52,53]. Two aspects have, proportionately speaking, been less often addressed in the academic literature: the role of designers (textile, fashion, etc.) $[51,54]$, and the role of the design of retail stores in contributing to sustainability objectives $[2,54,55]$.

\subsection{Online Corporate Sustainability Communication}

Interest in corporate sustainability increases each year and has promoted in organizations the development of adequate communication strategies to transmit their business approach to sustainability and corporate social responsibility (CSR) values [6] (p. 1). This has been even more the case in recent years, with digitalization placing the consumer or user at the center of conversations [56].

In this paper, we understand "sustainability communication" to mean all types of corporate and marketing communications about sustainability issues [6,57], including CSR communication that relates to issues of environmental protection and social responsibility in relation to economic success [3]. It should be taken into account that any analysis of the literature throws up a whole series of terms to refer to sustainable communication, such as the following: green communication, global responsibility communication, social responsibility communication and corporate sustainability communication [5,58].

In the digital communication environment, the web becomes a key tool as a meetingplace and point of interaction with all of the stakeholders. In this sense, for companies, 
the corporate website always plays a key role $[6,59]$ because it has the ability to transmit corporate statements and sustainability initiatives in a more direct and visual way.

In corporate sustainability communication, the sustainability report has recently turned out to be a central communication tool through which companies communicate their sustainability commitments and performance to their stakeholders. Since 2014, it has been mandatory for large companies in Europe to include this information in their Non-Financial Report (European Commission, 2014). In April 2021, the European Commission adopted a proposal for corporate sustainability reporting, effectively amending the previous requirements, extending the scope of companies, requiring audits of reported information and introducing mandatory European Union (EU) sustainability reporting standards (European Commission, 2021). Olofsson and Mark-Hebert [1] explain that sustainability reporting, as part of a company's communication strategy, shows not only the interest that a company has in terms of benefiting itself and its stakeholders, but also in terms of creating value for society at large.

However, the traditional media are being replaced by digital channels, and this also affects corporate communication, sustainability communication and CSR. "Online communication becomes a "key relational driver" that connects the company with its stakeholders, helps develop trusted relationships with them, and enhances corporate reputation" [6] (p. 3). In fact, as early as 2001, Wheeler and Elkington [60] questioned the future of the Corporate Environmental Report with the advent of the Internet and changing communication trends, this being a period in which all the possibilities of digital communication such as interaction, interactive graphics, videos, etc., had yet to be developed.

There is no doubt that CSR and the Sustainability Report will always exist [60], either in digital PDF or printed format, but that does not mean that PDF continues to be the best way to share the content with all of the stakeholders. The impact of the image and video on society shows a better level of communication engagement through these digital media.

We can state that digitalization has produced multiple changes in communication [61-63]: (i) it has resulted in more people being informed and having hundreds of sources of information at their disposal $[64,65]$. As a consequence, the messages that a company issues can be contrasted in a more efficient and more rapid manner. (ii) It allows the globalization of messages and ideas: an event in one place in the world can reach the entire planet, and messages shared on a web page can be seen and read by users everywhere [66,67]. (iii) Social networks allow conversations to be generated between companies and companies, companies and organizations, companies and users, organizations and users, and users and users. Conversations regarding environmental and social issues have increased and, therefore, so has everything relating to sustainability and CSR from a broader perspective [8,68-70]. (iv) The technology and development of image and video permit the development of a more interactive kind of communication, with graphics, videos and illustrations that facilitate the understanding of the messages [71,72].

However, all of these advances and changes also have a negative side or generate a risk. Due to the speed with which we can find information on the Internet, not to mention its global and free availability, we can find out about any initiative relating to the sustainability of any company in the world and, at the same time, about the errors or problems that companies may have relating to sustainability and CSR. These situations very often give rise to possible communication crises, because if companies fail to transmit the truth or fail to be transparent with regard to all of their activities relating to sustainability, this can cause controversy.

We cannot ignore the fact that, in recent years, consumers have become a main stakeholder, one to whom CSR and sustainability must be communicated. Society's awareness of the need to care for the planet, limited resources and the conditions of workers or animals, has led to a sustainability revolution. In part, this sustainability revolution, which the fashion industry plays a key role in, has been brought about thanks to the Internet and social networks. 
For this reason, it is more essential than ever that companies should behave ethically, in order to transmit these truths and avoid "cosmetic communication" [6]; that is to say, manipulating or hiding the most controversial aspects of corporate sustainability, also known as "greenwashing" [73-75] which especially affects the fashion industry [46]. In this sense, as explained above, fashion has been particularly affected by major environmental and social catastrophes [70].

It should be noted that from the perspective of management and its relationship with marketing, we can also find studies that analyze management's attitude to marketing and innovations in the luxury fashion industry. A recent investigation revealed that at some luxury companies, the marketing and innovation endeavors had very little in common with the CSR strategies and priorities officially established for the business [76] (p. 240). The authors state "identified rather a satisfactory (CSR) attitude of owners and senior managers, but also showed that low-level management often has a reduced knowledge and/or interest in linking the marketing and innovation functions with CSR best practice" (p. 240). The researchers conclude that: "It is amazing that luxury fashion businesses with such developed CSR statements and advertised marketing and innovation actions linked to basically all CSR categories have front-line employees, including managers, who do not share such commitments, and, instead, excessively go into auxiliary aspects and ultimately frustrate CSR approaches" (p. 240).

There is no doubt that, both with regard to the communication and the marketing of sustainability [77-79], whether offline and online, it is necessary for the whole company to be involved.

This explains our third research hypothesis: H3. Fashion companies and the fashion industry have an active communication strategy for sustainability.

The Web as a Tool to Communicate Sustainability

An increasing number of companies have corporate websites where there is a section or microsite dedicated to CSR and/or sustainability. In fact, some websites use the word "sustainability" as a title or key word to identify this section on the web. On this website, or in this section, they usually present sustainability organizational models, governance tools, sustainability or CSR, conduct and ethics codes, certifications and sustainability partnerships $[5,6,8]$.

Siano et al. [6] emphasize the fact that the web has brought more interactive reporting approaches in order to further involve stakeholders, stating that "interactive reporting, transparency and accountability have become the core elements of sustainability communication in digital contexts to ensure consistency between corporate commitment and the actions that are actually implemented" (p. 3).

As mentioned above, new trends in digital marketing, such as videos and content marketing, have influenced the communication strategies of companies. In the last three years, there has been a broad development of content marketing, a trend that has especially impacted the fashion industry. On websites, we can find stories, testimonials, success stories, editorial content on sustainable collections and content created by users. All of these tools can be employed to create a two-way communication approach focused on stakeholders, in general, or focused solely on the consumer.

In order to evaluate the impact of sustainability communication efforts on company websites, the literature [6,80] highlights three dimensions: (i) Content related to the core business, which refers to activities that have a strong impact on the area of business and the competitiveness of an organization; (ii) Content that impacts the value chain, i.e., initiatives that have a significant impact on the business processes and activities; (iii) Social content of generic interest, not significantly related to the core business of an organization but regarding generic philanthropic initiatives. Here we can envisage the triple bottom line [60] consisting of the economic, environmental and social aspects of sustainability.

Other key critical success factors regarding effective web-based corporate sustainability communications include accessibility; usability and website design; general website content; 
industry-specific sustainability issues as content; sustainability commitment; sustainability development agenda; contact feedback dialogue; sustainability reports [81] (p. 411).

Social media is another channel for external and internal corporate communication regarding sustainability, allowing companies to create direct two-way interactive communication with consumers. Therefore, more and more companies have adopted social media as an effective method of corporate communication [82].

Usually, corporate websites aim to communicate and engage multiple stakeholders. However, commercial websites, what are known as e-commerce, where consumers discover the brand and its products and can buy them, are sites that focus entirely on the consumer. In this respect, this study analyzes and compares corporate websites and e-commerce in the fashion industry for the first time.

This leads us to our fourth research hypothesis: H4. The sustainability communication of groups is different to that of brands, because the websites are focused on different stakeholders: the former are widely focused on the entire range of stakeholders (investors, civil society, other companies, competitors, etc.), and the latter are mainly focused on consumers.

\subsection{Online Corporate Communication regarding Sustainability in Fashion}

A recent study asked, "What consumer associations can build a sustainable fashion brand image?" [83]. The research, which focused on fast fashion companies, indicated three starting points (p. 1): "(1) there is a growing demand for sustainable fashion products from environmentally and socially conscious consumers; (2) fashion companies have begun applying sustainable business strategies, such as the presentation of sustainability labels and marketing campaigns; (3) when the perceived brand reputation is high, the perceived sustainability level only has a direct effect on purchasing intention, whereas when the perceived brand reputation is low, only the indirect effect of perceived skepticism appears".

Kim and Oh [83] conclude that any sustainable fashion product, even when a product with a high level of sustainability is provided, needs to always be accompanied by good communication and good marketing constantly to ensure that consumers are not suspicious.

As noted above, the web allows consumers and all of the stakeholders to directly offer sustainability information. Luxury groups such as Kering and LVMH currently publish their annual sustainability reports online. In the fashion industry, there is a need to constantly improve in the field of CSR and, at the same time, companies are increasingly required to communicate the social and environmental practices of their operations and supply chains in a clearer manner.

Although fashion companies have resources on hand to communicate their measures relating to sustainability, many of them still fail to share their social and environmental practices. In 2014, researchers Dach and Allmendinger [81], in their study on the corporate websites of the H\&M and Primark brands, concluded that there was a need for effective and credible web-based corporate sustainability communications, especially within the context of interactivity.

The communication of sustainability in fashion has always been a sensitive topic for companies. Managers are often afraid of the criticism they may receive because consumers regard the communication of the strategy and sustainable actions of the company to be greenwashing actions.

As Da Giau et al. [59] point out, few companies are carrying out effective communication strategies on the web in order to communicate their sustainable actions and practices to all of their stakeholders, ensuring that there is no friction between what they do and what they say they do in relation to the company's sustainable strategy.

One of the great fears for fashion companies is the lack of control they sometimes have over suppliers. For this reason, some companies are quite reluctant to create any form of external communication based on the web since "they do not want to risk communicating that they are developing sustainability practices, while they do not have full control over the situation of their suppliers" [59] (p. 84). Likewise, some fashion companies are also 
afraid to communicate these aspects due to the risk of being targeted and attacked by NGOs, who are prepared to analyze whether these sustainability actions are real.

For this reason, we find studies that have analyzed the corporate communication of sustainability online by focusing on the relationship between transparency and actions. "Corporate sustainability communications are increasingly important for providing consumers with the expected transparent information about corporate sustainability" [81] (p. 410).

In this sense, the work of Da Giau et al. classifies the relationship between web-based sustainability communication and sustainability practices into four groups: Low Disclosure (companies that are adopting the best sustainable practices, but that are not communicating the extent to which they are doing so); Low Commitment (companies that are poorly adopting sustainable practices and, consequently, have adopted infrequent or insufficient web-based communication); High Marketing (companies that are poorly adopting sustainable practices, but that are extensively communicating the few sustainability actions they have taken); and High Commitment (companies that are adopting the best sustainable practices and that are intensively communicating their efforts).

Other researchers have studied whether corporate fashion sustainability web pages create consumer awareness and influence their perceptions [81]. They claim that: "Only corporate sustainability communications that positively influence consumer awareness and perceptions are effective and contribute to realizing the benefits of a commitment to sustainability such as competitive advantages and increased buying behavior $[3,80,84]$. Since the Internet provides transparency, which is one of the most fundamental aspects of effective corporate sustainability communications" (p. 411).

In relation to the above, in the realm of fashion company communication, researchers have analyzed whether fashion retailers involve the consumer in their sustainability communication, and whether consumers create more awareness about sustainability, modifying fashion consumption patterns [32,36]. Researchers in this field point out that there is a lack of "consumer focus" in the sustainability practices of companies and warn that simply providing information is not enough to create awareness of sustainable consumption in fashion $[32,85]$.

Strähle et al. [32] "assume that sustainable fashion consumption can be achieved if the fashion retailer involves the consumer regarding the following aspects: A responsible usage phase, the importance of recycling clothing and/or offering options to bring back old clothing (garment collecting opportunities) and incentives to revise the own fashion consumption behavior" (p. 77). This type of practice is already a reality at some fashion companies, such as H\&M or Zara. Kusá and Urmínová [8] state, in this regard, that: "Environmental marketing communication has now become an inseparable part of consciousness in the field of sustainability and the fashion industry. Through their sustainable communication, companies try to reach as many people as possible. Digital technologies allow them to act both locally and globally. However, it is worth noting that the transition to sustainable growth may require big changes, but these are individuals who have the power to change the entire world (Sherin 2013). Digital tools allow sustainable communication to spread among people and consumers through different platforms: media, social networks, company websites, blogs or applications" (p. 2).

Sustainability communication aimed at consumers performs an educational function that promotes changes in the fashion industry. Moorhouse and Moorhouse [86] state that consumers still continue to believe that communication efforts in this area are insufficient [8] and how this makes consumers want to change their attitude towards a specific brand that respects the environment $[8,87]$. Kusa asked consumers how they preferred to obtain communications regarding sustainable fashion, and they indicated social media, articles on the Internet and influencers as the preferred channels. However, Kusa did not include web pages amongst the response options.

Most of the companies have their website active in order to promote the differentiation of their brand among consumers and electronic purchases; that is to say, they are not normally created in order to communicate their sustainable strategy and their initiatives 
in this regard [59]. As we shall see in this paper, at present we can observe the fact that corporate websites certainly do have the objective of communicating sustainability initiatives, whilst brand websites support brand differentiation among consumers and promote e-shopping [88].

In order to find out what kind of information is disclosed on websites, we formulated our fifth hypothesis: H5. The communication of sustainability in the specification details for products is aimed at stimulating sustainable purchasing and, to a certain extent, is linked to "greenwashing" practices.

Although this research does not focus on the effects of communication and marketing sustainability on consumer behavior, we cannot forget that researchers such as Lim $[89,90]$ highlighted the importance of increasing sustainable marketing efforts to produce a positive effect on the sustainable consumption. Promoting conscientious and responsible consumption will make sustainability not only an issue that worries companies, but also that the consumer has social, environmental and ethical concerns that can be translated into sustainable consumption decisions for the good of society, people and the planet [89].

\section{Methodology and Sample}

\subsection{Methodology}

This paper is based on the Operational Model for Evaluating Corporate Websites (OMECW) developed by Siano et al. [6]. This model identifies the core dimensions of online sustainability communication (orientation, structure, ergonomics and contentOSEC), having been applied to the corporate websites of energy and utility companies. After analyzing the literature, we have reached the conclusion that this is the most complete model when it comes to analyzing communication about sustainability on web pages. It should be noted that all of the studies we have reviewed that analyze communication regarding sustainability on websites have focused on analyzing corporate websites.

Apart from the four core dimensions, there are various sub-dimensions, such as stakeholder engagement and governance tools, communication principles and measurable items (e.g., presence of the materiality matrix, interactive graphs) [6] (p. 1).

Given that this model dates from 2016 and is not focused on websites in the fashion industry, it was necessary to review and update the items and adapt the current analysis to the fashion industry. This process was carried out in the following stages:

- The way of presenting the items has been updated, including changes in the subdimension and items relating to expressions and order;

- Other sub-dimensions and items from other studies relating to the evaluation of fashion sustainability communication $[5,32,81]$ through the web have been added;

- The name of the sub-dimension in the orientation dimension has been changed in order to adapt it to the new way of presenting organizations and web sections on sustainability;

- We have added a new sub-dimension, based on the literature, this being one of great importance to the fashion industry: "Consumer Involvement";

- Once we had developed the main model for fashion corporate websites, a new version was made for e-commerce, adapting certain items with regard to the corporate version.

In this manner, we were able to develop a new OMECW-OSEC model that applies to the fashion industry, which shall be called the Operational Model for Evaluating Fashion Corporate Websites (OMEFCW-OSEC) (see Appendix A). For the e-commerce analysis, the adapted model shall be known as the Operational Model for Evaluating Fashion E-Commerce (OMEFeC-OSEC) (see Appendix A). We can summarize these models as follows:

- OMECW-OSEC: 4 dimensions, 18 sub-dimensions, 64 items;

- OMEFCW-OSEC: 4 dimensions, 23 sub-dimensions, 95 items;

- OMEFeC-OSEC: 4 dimensions, 23 sub-dimensions, 99 items.

As we have seen, the model analyzes four dimensions that constitute the core elements that impact the effectiveness of sustainability communication activities on corporate websites. These dimensions include orientation, structure, ergonomics and content. Every 
dimension is made up of several sub-dimensions and specific measurable items. The creation of the sub-dimensions and the item selection process is explained in depth in Siano [6]. The four dimensions are highlighted below:

1. Orientation: this is the strategic approach that defines the core elements of the corporate identity in relation to sustainability. The sub-dimensions consist of the two sections where the company can define its strategy or mission. In the original model [6], this sub-dimension focused on the mission and vision of the company, but today, when communication is carried out, mission and vision are no longer explicitly mentioned. It consists of general texts in which the company's commitment to sustainability issues is presented in general; for this reason, two new sub-dimensions are analyzed: About Us and the Sustainability web section/microsite.

2. Structure: this consists of a set of organizational tools and aspects that are able to support the credibility of the information conveyed and the relationships with users on the website [6]. The four sub-dimensions have been maintained: Stakeholder Engagement Sections, Stakeholder Engagement Tools, Governance of Sustainability: Organizational Model and Governance of Sustainability: Tools/Resources of Corporate Identity. Some expressions were adapted, and two items were added in total.

3. Ergonomics: this is the ability of the website to ensure an easy navigation process and an appropriate viewing of contents by users [6]. The same sub-dimensions were maintained: Accessibility; Navigability; Usability; Interactivity; Multimedia. In total, eight new items were added, which is due to ongoing digital innovations that have improved and changed websites a great deal since 2016.

4. Content: this relates to the corporate sustainability presented through the website. The sub-dimensions refer to content concern of "sustainability initiatives". Siano's seven sub-dimensions were maintained (Initiatives of Corporate Sustainability; Principle of Comm.: Visibility; Principle of Comm.: Clarity; Principle of Comm.: Authenticity; Principle of Comm.: Accuracy; Principle of Comm.: Consistency; Principle of Comm.: Completeness), featuring a total of 22 items. In addition, 4 new sub-dimensions were added (General Website Content; Industry-specific Sustainability Issues as Content; Contact, Feedback, Dialogue; Sustainable Development Agenda; Consumer Involvement), with 20 new items. The great novelty that this study contributes is to analyze consumer involvement in some depth: those web contents that are directly linked to information and actions that influence consumer behavior.

As can be seen in Appendix A, in the OMEFeC-OSEC model, the Stakeholder Engagement Tool sub-dimension is eliminated since the web is focused only on consumers, whilst the Consumer Involvement sub-dimension is divided into two: Consumer Involvement in Sustainability Section, and Consumer Involvement in Product Specification Details.

Siano [6] explain that in order to measure the value of each dimension, all of the items that have been identified in the model have been analyzed as dichotomous (dummy) variables. Consistent with Siano, this type of choice was justified by the fact that they entail less difficulty in operationalization compared to variables that are detectable with scaling techniques. The OMEFCW and OMEFeC models use the same method to measure the value of each dimension. As stated by Siano [6]: "Although there is no universally agreed method to measure the communication of sustainability, the OSEC model proposes a comprehensive way of analyzing it, assuming that the disclosure of information on different facets of sustainability will have repercussions that are positive in the effectiveness of company communication. A proper interpretation of the results can help to understand and evaluate digital communication on sustainability “(p. 7).

As a consequence, in order to measure the effectiveness of communication, the researchers designed different score ranges that could be analyzed to interpret the results. Therefore, they considered that the maximum score $(s=100)$ identifies a company that presents a complete compliance with requirements for an effective sustainability communication. They described five ranges (p. 8): 
1. $s>80$. This score range includes firms that show an excellent compliance with sustainability communication requisites.

2. $70<\mathrm{s}<79$. This type of result indicates firms that fulfil communication requirements in a satisfactory way.

3. $60<\mathrm{s}<69$. This range presents firms with an acceptable compliance with communication requisites. Improvement actions are, however, possible in different dimensions.

4. $50<\mathrm{s}<59$. Firms in this range show some weaknesses in digital sustainability communication. Several changes are required to avoid reputational risks.

5. $\mathrm{s}<49$. In the last range, firms present poor compliance with communication requirements. A complete revision of digital communication strategies and practices is needed.

Two researchers analyzed all of the websites and structured the responses into a data matrix to code each website. We follow Siano's coding scheme, assigning the corresponding value for each item of the model ( $0=$ in case of absence; $1=$ if the requirement is judged as fulfilled). A satisfactory level of initial agreement was reached (Krippendorff's $\alpha=0.90$ ).

The sample is explained below. Then we shall proceed to the Results and Discussion sections.

\subsection{Sample}

In order to carry out this study, we selected the biggest and most representative groups on the mass market and luxury market in Europe in terms of revenue (Table 1), groups that also have comparable brands in clothing and accessories for each segment: H\&M, Inditex, Kering and LVMH.

H\&M, Inditex and Kering are all founding signatories of the United Nations Fashion Industry Charter for Climate Action (2018) and of the Fashion Pact (2019). They are committed to the main fashion alliances for a more sustainable industry. On the contrary, LVMH has not signed these agreements and this group is more inclined to act on its own, as its Head of Communications and Image stated in 2019: "We prefer act to pact" [91].

Table 1. Main characteristics of the groups analyzed.

\begin{tabular}{ccccc}
\hline Fashion Model & Company Group & * Revenue USD & $\begin{array}{c}\text { * Number of } \\
\text { Employees }\end{array}$ & $\begin{array}{c}\text { Number of } \\
\text { Clothing } \\
\text { Brands }\end{array}$ \\
\hline Fast Fashion & H\&M Group & 22.0 billion & 110,325 & 7 \\
Fast Fashion & Inditex Group & 24.8 billion & 144,116 & 7 \\
Luxury & Kering Group & 16.1 billion & 38,553 & 6 \\
Luxury & LVMH Group & 54.8 billion & 150,479 & 12 \\
\hline
\end{tabular}

${ }^{*}$ Data from Orbis database 2020.

H\&M Group has a sustainability strategy based on three pillars: leading the change, circular and climate positive, and fair and equal. This is its approach when it comes to tackling the three dimensions of sustainability: economic, environmental and social. As of 2021, the group has added a series of stories highlighting its main achievements and best practices to its annual Sustainability Performance Report.

Inditex has designed a sustainability roadmap for its value chain, founded on two cornerstones: a commitment to the circular economy and decarbonization; and full compliance with the Sustainable Development Goals [92] (p.76). In the group's document "Our Commitment to Sustainability", it summarizes the objectives for each step of the value chain: design: sustainable raw materials; manufacturing: environment health and safety; distribution: green packaging and warehouse management; stores: eco-efficiency and sustainable packaging, as well as the clothes collecting program. Or, as the group declares on its website: Right to Wear (human rights and partnerships), Commitment to People (employees, suppliers, tax contribution and supporting communities) and Commitment to the Environment (water, climate change and energy, biodiversity and closing the loop). 
Kering's sustainability strategy is based on "Care, Collaborate and Create": care is more related to reducing the group's environmental footprint and preserving the planet, collaborate relates to stakeholders and create means creating innovative alternatives through innovation.

LVMH has a social and environmental responsibility commitment, with seven initiatives highlighted on the group's website: Maison 0 (partnership with Central Saint Martins to promote young designers); Life 360 (environmental initiatives: biodiversity, circularity and transparency); the Environment Academy (to train employees in the protection of human resources), LIFE in stores (to reduce the group's environmental footprint), Dîner des Maisons ngagées (charities), EllesVMH (to encourage the professional development of women) and Care for Models (to ensure their well-being). The commitment does not only encompass clothing, but also the group's other brands (wines, food, cosmetics, watches, etc.).

The experimental part of this research began the first of April 2021. Since then, we have observed many changes regarding the content and appearance of the websites (Table 2), both corporate and relating to the brands. We reviewed the web pages in August 2021, and we updated our previous analysis. This confirms that there is an increasing interest in communicating sustainability.

Table 2. Specific section on sustainability for the websites sample in the study.

\begin{tabular}{|c|c|c|c|c|}
\hline Fashion Model & $\begin{array}{l}\text { Company } \\
\text { Group }\end{array}$ & $\begin{array}{l}\text { Corp. } \\
\text { Sustainability } \\
\text { Web }\end{array}$ & Brands Group & $\begin{array}{l}\text { E-Commerce } \\
\text { Sustainability } \\
\text { Section }\end{array}$ \\
\hline Fast Fashion & $\begin{array}{c}\text { H\&M Group } \\
(6 / 7)\end{array}$ & $\checkmark$ & $\begin{array}{c}\text { H\&M } \\
\text { COS } \\
\text { WEEKDAY } \\
\text { MONKI } \\
\text { Afound } \\
\text { \& Other Stories } \\
\text { ARKET }\end{array}$ & $\begin{array}{l}\checkmark \\
\checkmark \\
\checkmark \\
\checkmark \\
- \\
\checkmark \\
\checkmark\end{array}$ \\
\hline Fast Fashion & $\begin{array}{c}\text { Inditex Group } \\
(7 / 7)\end{array}$ & $\checkmark$ & $\begin{array}{c}\text { Zara } \\
\text { Pull\&Bear } \\
\text { Massimo Dutti } \\
\text { Bershka } \\
\text { Stradivarius } \\
\text { Oysho } \\
\text { Uterqüe }\end{array}$ & $\begin{array}{l}\checkmark \\
\checkmark \\
\checkmark \\
\checkmark \\
\checkmark \\
\checkmark \\
\checkmark\end{array}$ \\
\hline Luxury & $\begin{array}{l}\text { Kering Group } \\
\qquad(3 / 6)\end{array}$ & $\checkmark$ & $\begin{array}{c}\text { Gucci } \\
\text { Saint Laurent } \\
\text { (YSL) } \\
\text { Balenciaga } \\
\text { Bottega Veneta } \\
\text { Alexander } \\
\text { McQueen } \\
\text { Brioni }\end{array}$ & $\begin{array}{l}\checkmark \\
\checkmark \\
- \\
- \\
- \\
\checkmark\end{array}$ \\
\hline Luxury & $\begin{array}{l}\text { LVMH Group } \\
\qquad(4 / 12)\end{array}$ & $\checkmark$ & $\begin{array}{c}\text { Loewe } \\
\text { Moynat } \\
\text { Louis Vuitton } \\
\text { Berluti } \\
\text { Loro Piana } \\
\text { Fendi } \\
\text { Celine } \\
\text { Christian Dior } \\
\text { Emilio Pucci } \\
\text { Givenchy } \\
\text { Kenzo } \\
\text { Marc Jacobs }\end{array}$ & $\begin{array}{l}\checkmark \\
- \\
\checkmark \\
- \\
- \\
\checkmark \\
- \\
- \\
- \\
- \\
- \\
\checkmark\end{array}$ \\
\hline
\end{tabular}


In our initial approach to the sample, we found that the four corporate websites included a specific section on sustainability. When we went to the e-commerce websites of the brands, the situation was different.

All of the brands that make up the H\&M Group have a specific section, except for Afound. This brand has an "editorial", which includes advice, inspiration and guidance regarding many subjects, ranging from dress codes for different events to how to remove stains or how to take care of garments in the use phase (washing, drying, etc.). This might be a means of education for the purchaser to extend the garments' lifespan.

All of the brands that make up Inditex have a section on sustainability. When we began our research, Stradivarius did not have one (or it was not visible to the consumer). This brand only showed the Join Life Collection, but it was not highlighted on the menu. By August 2021, there was a complete Join Life section featuring all of the corresponding information regarding sustainability.

Only half of the houses of Kering had a section on sustainability: Gucci, Yves Saint Laurent (YSL) and Brioni. YSL incorporated this section (or made it visible) during our research: In August 2021, the section was accessible on the home page, both under the "La Maison" section and on the right, close to the buying section. Searching for "Sustainability" at Balenciaga, certain products appeared (e.g., messenger bag in "photosensitive sustainable casual nylon"). Bottega Veneta and Alexander McQueen revealed 0 results in the same search.

When analyzing the houses of the LVMH Group, the information on sustainability was reduced to one third of the clothing brands: Loewe, Louis Vuitton, Fendi and Marc Jacobs. Dior does not have any section on sustainability; searching for this term in the browser, there are three results, all of them relating to cosmetics (refillable lipstick, make-up and cream). Although Emilio Pucci does not have any section or microsite about sustainability, by searching on the browser we came across a "sustainable-edit" section with 77 pieces. In some of them (not in all), the text presents a brief description of the "sustainable" attributes, e.g., eco-Lycra, but without explaining why the Lycra is eco. Givenchy shows 0 results when searched for the term "sustainability", and the same applies to Kenzo, Loro Piana, Moynat, Berluti and Celine.

This initial approach, in which nearly all of the fast fashion brands had a specific section on sustainability and less than half of the luxury brands did, would be consistent with the aforementioned findings [38], namely that sustainable communication creates dissonant and conflicting associations for luxury brands, being more congruent with non-luxury brands.

The sample was stable in the case of the corporate websites (the content was updated during our research but did not feature excessive changes). On the contrary, the brands websites changed much more in terms of their appearance, format and content over the five months (e.g., Brioni and Marc Jacobs had a website map in April-May and they removed it by August; Fendi had always displayed the "Sustainability" Section under "Corporate", but by the end of our research it was necessary to unfurl the "Corporate" menu in order to find it, which made it more difficult to access.

We can also observe different ways of disclosing information about sustainability amongst the various groups and brands. To cite only a few examples: through microsites (H\&M, Inditex, Fendi, Brioni); through social and environmental initiatives (LVMH); inside the magazine, without specific titles or correlation of the content (Louis Vuitton, although it is also accessible through a button on the homepage); very sparsely (Marc Jacobs). There are also differences in the way in which the results and objectives are presented (year by year; $\%$ of achievements; paragraphs with the information embedded, which makes it more difficult to read, etc.)

\section{Results and Discussion}

In this section, first the results relating to the fashion groups will be presented. Then, the results relating to the fashion brands will be explained. In addition, finally, a comparison will be made between the corporate and e-commerce websites. 


\subsection{Company Groups}

The H\&M and Kering groups are the ones with the highest score, both achieving the same: 80.20 , as the Table 3 shows. This result shows that in relation to the corporate websites of fashion groups, sustainability communication can include a score range that shows an excellent compliance to sustainability communication requirements, both in the case of luxury groups and in the case of fast fashion. LVMH almost reaches 80 points, whilst Inditex, with a score of 76 , is the group with the lowest score, although it is within the range of brands that fulfil communication requirements in a satisfactory manner. As we can see in the table, the greatest difference between the groups is in the Content dimension: Inditex and LVMH are the ones that can improve the most in this regard.

Table 3. Results of the OMEFCW-OSEC analysis of the fashion groups in our sample.

\begin{tabular}{cccccc}
\hline Group & Orientation & Structure & Ergonomics & Content & Total \\
\hline & $0-9.37$ & $0-18.75$ & $0-28.13$ & $0-43.75$ & \\
Inditex & 9.37 & 14.58 & 20.83 & 31.25 & 76.03 \\
H\&M & 9.37 & 14.58 & 18.75 & 37.50 & 80.20 \\
Kering & 9.37 & 13.54 & 20.83 & 36.46 & 80.20 \\
LVMH & 9.37 & 14.58 & 21.87 & 33.33 & 79.15 \\
\hline
\end{tabular}

In relation to the other dimensions, we can see that in relation to Structure, they all have the same score, except for one point less in the case of Kering. Under Ergonomics, the highest score is for LVMH and the lowest for H\&M. The efficiency of the best brand in Ergonomics is $77.74 \%$, in Content it is $76.18 \%$ and in Structure it is $77.76 \%$. In other words, the field in which the greatest improvement can be made is Content. Both luxury groups achieve a joint score of 159.35, which is a better figure than the mass market groups of 156.23. The statistical values of the OMEFeC - OSEC analysis of the fashion groups in our sample, are analyzed in Table 4.

Table 4. Statistical values in the OMEFeC-OSEC analysis of the fashion groups in our sample.

\begin{tabular}{ccccccc}
\hline & & Orientation & Structure & Ergonomics & Content & Total \\
\hline \multirow{2}{*}{$\begin{array}{c}\text { Positional } \\
\text { values }\end{array}$} & Maximum & 9.9 .37 & $0-18.75$ & $0-28.13$ & $0-43.75$ & 100 \\
& Minimum & 9.37 & 14.58 & 21.87 & 37.50 & 80.20 \\
\multirow{2}{*}{$\begin{array}{c}\text { Synthetic } \\
\text { values }\end{array}$} & Median & 3.03 & 13.54 & 18.75 & 31.25 & 76.03 \\
& Mean & 3.00 & 1.58 & 11.74 & 14.52 & 30.84 \\
& Std dv & 2.77 & 2.19 & 9.50 & 13.65 & 26.43 \\
\hline
\end{tabular}

\subsection{Fashion Brands}

In our analysis of sustainability communication on the websites of fashion brands, fashion e-commerce, in accordance with the ranges described in the Methodology Section [6], the scores were as follows (Table 5):

Gucci, with 75.75 points, fulfils the communications requirements in a satisfactory manner. MONKI, with H\&M and YSL (more than 60.60) show acceptable compliance with the communication requisites. Zara, Massimo Dutti, Stradivarius (all on 58.58); Louis Vuitton (55.55); Bershka (53.53), Pull\&Bear (51.51) and Oysho and Fendi (both on 50.50) show some weaknesses in digital sustainability communication. In the last range, WEEKDAY, ARKET, COS, Loewe, \& Other Stories, Uterqüe, Brioni and Marc Jacobs (with the lowest score of 23.23) present poor compliance with the communication requisites.

Therefore, none of the brands are excellent (as they do not reach 80 points); among the four best brands, we have two luxury brands and two fast fashion brands; the situation is the same among the four worst brands. 
Table 5. Results of the OMEFeC-OSEC analysis of the fashion brands in our sample.

\begin{tabular}{|c|c|c|c|c|c|}
\hline Brand & Orientation & Structure & Ergonomics & Content & Total \\
\hline & 0-9.09 & $0-15.15$ & $0-27.27$ & $0-48.49$ & \\
\hline $\mathrm{H} \& \mathrm{M}$ & 4.04 & 4.04 & 20.20 & 32.32 & 60.60 \\
\hline COS & 5.05 & 2.02 & 18.18 & 18.18 & 43.43 \\
\hline WEEKDAY & 5.05 & 1.01 & 17.17 & 25.25 & 48.48 \\
\hline MONKI & 8.08 & 7.07 & 19.19 & 35.35 & 69.69 \\
\hline Afound & 0 & 0 & 0 & 0 & 0 \\
\hline $\begin{array}{l}\text { \& Other } \\
\text { Stories }\end{array}$ & 2.02 & 1.01 & 17.17 & 11.11 & 31.31 \\
\hline ARKET & 7.07 & 1.01 & 16.16 & 23.23 & 47.47 \\
\hline Zara & 5.05 & 2.02 & 20.20 & 31.31 & 58.58 \\
\hline Pull\&Bear & 3.03 & 2.02 & 20.20 & 26.26 & 51.51 \\
\hline $\begin{array}{l}\text { Massimo } \\
\text { Dutti }\end{array}$ & 5.05 & 2.02 & 22.22 & 29.29 & 58.58 \\
\hline Bershka & 5.05 & 2.02 & 23.23 & 23.23 & 53.53 \\
\hline Stradivarius & 5.05 & 2.02 & 21.21 & 30.30 & 58.58 \\
\hline Oysho & 5.05 & 2.02 & 20.20 & 23.23 & 50.50 \\
\hline Uterqüe & 2.02 & 0.00 & 19.19 & 4.04 & 25.25 \\
\hline Gucci & 6.06 & 9.09 & 22.22 & 38.38 & 75.75 \\
\hline YSL & 9.09 & 4.04 & 19.19 & 28.28 & 60.60 \\
\hline Balenciaga & 0 & 0 & 0 & 0 & 0 \\
\hline $\begin{array}{l}\text { Bottega } \\
\text { Veneta }\end{array}$ & 0 & 0 & 0 & 0 & 0 \\
\hline A. McQueen & 0 & 0 & 0 & 0 & 0 \\
\hline Brioni & 3.03 & 0.00 & 14.14 & 11.11 & 28.28 \\
\hline Loewe & 3.03 & 1.01 & 18.18 & 13.13 & 35.35 \\
\hline Moynat & 0 & 0 & 0 & 0 & 0 \\
\hline Louis Vuitton & 5.05 & 2.02 & 20.20 & 28.28 & 55.55 \\
\hline Berluti & 0 & 0 & 0 & 0 & 0 \\
\hline Loro Piana & 0 & 0 & 0 & 0 & 0 \\
\hline Fendi & 5.05 & 5.05 & 15.15 & 25.25 & 50.50 \\
\hline Celine & 0 & 0 & 0 & 0 & 0 \\
\hline $\begin{array}{l}\text { Christian } \\
\text { Dior }\end{array}$ & 0 & 0 & 0 & 0 & 0 \\
\hline Emilio Pucci & 0 & 0 & 0 & 0 & 0 \\
\hline Givenchy & 0 & 0 & 0 & 0 & 0 \\
\hline Kenzo & 0 & 0 & 0 & 0 & 0 \\
\hline Marc Jacobs & 3.03 & 1.01 & 12.12 & 7.07 & 23.23 \\
\hline
\end{tabular}

From the H\&M Group, the brand with the best score is MONKI (in all four dimensions) and the ones that have the worst score are \& Other Stories and Afound, with 0 points. The average score for the H\&M Group brands is 50.16 if we consider the brands that have a sustainability section on their own, and 42.99 if we also include Afound.

From the Inditex Group, the best brands (with the same score) are Zara, Massimo Dutti and Stradivarius. The worst brand by far is Uterqüe. As we have commented previously, the most differential dimension is Content and, within this dimension, the brand that performs the best is Zara. All of the brands have a specific section on sustainability, which results in a higher average of 50.93, Inditex being the best performer in our sample as a group.

With regard to the websites of the luxury brands, we can see that the average score for the Kering Group is 54.87, if we consider the three brands that have a sustainability section on their own. This score falls to 9.14 points if we analyze the group with all six brands, three of which score 0 . Although Gucci is the best performer among the brands in our study, this is not translated to the rest of the group.

From the LVMH Group, the brand with the best sustainability communication is Louis Vuitton with 54.55 points, whilst the worst is Marc Jacobs with 23.23 points, the average group scores being 41.15 (considering the four brands that have sustainability information) and 3.42 (with all 12 brands in the sample). Once the brands of each group have been 
analyzed, we can describe, through the Statistical Values (Table 6), the behavior of all fashion brands as a group in relation to the four dimensions.

Table 6. Statistical values in the OMEFeC-OSEC analysis of fashion brands.

\begin{tabular}{ccccccc}
\hline & & Orientation & Structure & Ergonomics & Content & Total \\
\hline \multirow{2}{*}{$\begin{array}{c}\text { Positional } \\
\text { values }\end{array}$} & Maximum & 9.09 & $0-15.15$ & $0-27.27$ & $0-48.49$ & 100 \\
& Minimum & 0 & 9.09 & 23.23 & 38.38 & 75.75 \\
\multirow{2}{*}{$\begin{array}{c}\text { Synthetic } \\
\text { values }\end{array}$} & Median & 3.03 & 0 & 0 & 0 & 0 \\
& Mean & 3.00 & 1.01 & 16.67 & 12.12 & 33.33 \\
& Std dv & 2.77 & 2.19 & 11.74 & 14.52 & 30.84 \\
\hline
\end{tabular}

Based on these results, the sample analyzed as a whole would be ranked as a poor compliant with the communication requisites since the mean comes to 30.84 points.

The coefficient of variation helps us to understand the deviation of data within the context of the mean. We can observe a high coefficient in all the variables, especially in Structure, with a value of $139 \%$.

Nevertheless, as we have seen above, there is a considerable deviation between corporate and brands, and brands and brands. Despite this, the OMEFCW and OMEFeC models turn out to be consistent with the performance of the groups and brands in terms of sustainability.

Gucci, the best rated, has an extensive microsite, "Gucci Equilibrium", which is quite complete in terms of content and performance.

The H\&M brand has great potential to educate the consumer, given that it presents the "product background" of each product, containing information about the materials, the suppliers and factories (name, country, address, number of workers), how to care for the garment and how to recycle it. Zara also offers extensive information about each product, including certifications and the country where it has been made (not the factory).

COS has a great commitment on sustainability, but this is not entirely communicated through its website, although abundant information is shared with customers via e-mail. The main bulk of consumers at COS probably buy products based on their knowledge of these sustainable attributes, but the website should reflect this commitment better.

Even in the same fashion group, brands act in different ways in relation to sustainability, as they do with regard to other aspects. For instance, while Kenzo and Marc Jacobs offer summer sales of up to $50 \%$ or $40 \%$ off, respectively, Louis Vuitton states on its website that it never discounts its products, even though the three houses all belong to the LVMH Group.

\section{Conclusions}

In recent years, the sustainability strategy at fashion companies has been gaining importance, becoming a central issue at the heart of the fashion industry. These strategies have led to multiple studies, consulting reports, conferences, awards and academic research. The COVID-19 pandemic has simply boosted interest and concern regarding sustainability, not only of the planet, but also of people and work systems, all under the umbrella of the circular economy.

In light of our considerations in the first section of this paper, it might seem that sustainability has become a key aspect for the success of fashion companies in the 2020s, as $\mathrm{H} 1$ indicates and described in the first section of this article. However, the research results have shown that there are still many improvements that fashion companies can make, and although fashion business groups show themselves to be "sustainable", fashion brands still have a long way to go in this regard. 
The same logic applies to $\mathrm{H} 2$ and H3. At a theoretical level, it seems that luxury and fast fashion brands are equally interested in the communication of sustainability and pursue active sustainability communication strategies. However, once again, it has been observed in this study that although fashion groups endeavor to communicate sustainability well, the brands that make up these groups do not always do so.

Our analysis of sustainability communication on corporate websites was mainly carried out around 2016. With the ongoing digital revolution, it was necessary to review the literature and propose a new updated analysis method. Studies of the corporate websites of fashion groups were limited, especially in relation to the dimensions of the items being analyzed. The new OMEFCW-OSEC model we have proposed presents a new way of analyzing the corporate websites of fashion groups in depth, with both crucial managerial implications on brand impact and corporate reputation and academic contribution to the topic researched.

There was no adequate model to analyze the communication of sustainability at fashion brands. The adaptation of the OMEFCW-OSEC model to create an OMEFeCOSEC model allowed us to analyze the communication of all the of the brands' websites in a comprehensive and effective manner.

The results from our model applied to the corporate websites prove our first hypothesis, H1, namely that sustainability has become a key aspect for the success of fashion companies. These results only partially confirm our third hypothesis, H3, namely that fashion companies and the fashion industry pursue an active communication strategy regarding sustainability, because only 24 out of the 36 websites analyzed (both groups and brands) conformed to this idea $(66.6 \%)$.

The inclusion of the Consumer Involvement sub-dimension and its adaptation to the sustainability communication that brands send to fashion consumers in their e-commerce is both correct and necessary. Consumers are increasingly demanding clearer, more attractive and binding information on sustainability. Fashion brand websites have the opportunity to educate consumers and positively influence their conscious and sustainable fashion purchasing decisions. This opportunity is too good to be missed.

Although corporate websites communicate very well on issues relating to sustainability in all of the dimensions, the same does not happen in e-commerce. Many e-commerce websites for luxury brands do not have any section relating to sustainability. It is striking that the group takes so much care in its corporate communication and yet does not ensure that all of its brands have a good sustainability strategy and a good sustainability communication strategy. This type of inconsistency could be viewed as "greenwashing" at the corporate level.

This confirms our H4, namely that sustainability communication at groups is different to that of the brands. The main reason for this possible incoherence is due to the fact that in the luxury fashion segment, each brand within a group has a great deal of autonomy in terms of actions and strategic decisions.

On the contrary, the greater uniformity seen amongst fast fashion groups shows how all of the brands, even if they have some degree of autonomy, are more influenced by the strategic guidelines they receive from the group. A clear example of this is the Inditex Group and its brands, where many of the e-commerce operations achieve a similar score.

This does not confirm our second hypothesis, H2, which states that both luxury and fast fashion brands are equally interested in the communication of sustainability. There is great asymmetry between them in terms of the number of brands (13 out of 14 in fast fashion and 7 out of 18 in luxury fashion), although when luxury brands communicate, they can do it very well.

In relation to $\mathrm{H} 5$, the study of items from the Consumer Involvement sub-dimension in the Content dimension (visibility of information on product origin and traceability, clothing care during usage phase, clothing end-of-life process/recycling and sustainable consumption) shows that only the H\&M brand meets four criteria, and five brands in total communicate product origin and traceability. 
The communication of sustainability in the product specification details may be oriented towards stimulating sustainable purchasing in some cases (e.g., H\&M, Zara), where it provides traceability and certifiable data (although incomplete), and it might be related to "greenwashing" practices when it relates to vague adjectives such as "eco" and "sustainable", without any further definition (e.g., Dior, Marc Jacobs, etc.).

Finally, we can conclude that, although more and more efforts are being made to communicate sustainable strategies and actions, there is still a long way to go, especially in e-commerce, which is the preferred place for the consumer to discover products and buy them. Fashion brands must continue to improve their communication strategies in the knowledge that they can have an educational and awareness-raising impact on consumers.

\subsection{Managerial Implications}

This study could be highly useful for fast fashion and luxury fashion brands that wish to improve their sustainability communication strategies, both at the corporate level and in relation to each of the brands that make up the group.

The conclusions highlight how luxury groups should involve all of the brands in the communication strategy for initiatives and actions relating to sustainability. The analysis method developed in this paper could provide a roadmap for businesses to discover which communication aspects they need to improve in order to launch or boost their communication plan.

All of the companies in the fashion industry must increase their marketing and sustainable communication efforts in order to drive more sustainable consumer behavior.

\subsection{Limitations}

The study sample is limited. Although the most important groups in Europe in the fields of fast fashion and luxury fashion have been analyzed, it is necessary to study a larger number of groups and brands in order to see whether this model can also be applied to small and medium-sized companies.

\subsection{Future Studies}

Future studies will have to address the limitations indicated above and test the effectiveness of the method amongst non-European fashion groups. In addition, it may be necessary to link the results with the thinking and vision of those responsible for sustainability, as well as the perception of consumers within the sample that is analyzed.

Furthermore, in the online world of fashion, social media is becoming increasingly important as a direct two-way communication channel vis-à-vis the end consumers. Analyzing the communication strategies relating to the sustainable strategies of companies will be of great interest and, at the same time, it will be possible to evaluate the interactions of users and consumers on these social platforms.

Author Contributions: P.S. and S.P.-B. developed the conceptualization, methodology, validation and analysis, and produced the original draft. T.S. and P.M.-B. reviewed and edited the paper. All authors have read and agreed to the published version of the manuscript.

Funding: This research received no external funding.

Institutional Review Board Statement: Not applicable.

Informed Consent Statement: Not applicable.

Data Availability Statement: The data presented in this study are available on request from the corresponding author.

Conflicts of Interest: The authors declare no conflict of interest. 


\section{Appendix A}

Table A1. Operational Model for Evaluating Fashion Corporate Websites (OMEFCW-OSEC).

\begin{tabular}{|c|c|c|c|c|}
\hline Dimensions & Sub-Dimensions & $\mathbf{N}^{\mathbf{o}}$ & Items & Author Reference \\
\hline \multirow{9}{*}{ Orientation (9) } & \multirow{3}{*}{ About us } & 1 & Explicit references to sustainability & [6] \\
\hline & & 2 & Explicit references to environmental sustainability & {$[6]$} \\
\hline & & 3 & Explicit references to people (sustainability) & Adapted from [6] \\
\hline & \multirow{6}{*}{$\begin{array}{c}\text { Sustainability } \\
\text { web } \\
\text { section/microsite }\end{array}$} & 4 & Explicit references to sustainability & {$[6]$} \\
\hline & & 5 & Explicit references to environmental sustainability & {$[6]$} \\
\hline & & 6 & Explicit references to people (sustainability) & Adapted from [6] \\
\hline & & 7 & Sustainability strategy & [81] \\
\hline & & 8 & Top management commitment & [81] \\
\hline & & 9 & Most important sustainability challenges mentioned & [81] \\
\hline \multirow{18}{*}{ Structure (18) } & \multirow{5}{*}{$\begin{array}{l}\text { Stakeholder } \\
\text { engagement } \\
\text { sections }\end{array}$} & 10 & $\begin{array}{c}\text { Numerous website sections dedicated to stakeholder } \\
\text { groups }\end{array}$ & Adapted from [6] \\
\hline & & 11 & $\begin{array}{c}\text { Numerous typical elements in section dedicated to } \\
\text { investor relation }\end{array}$ & Adapted from [6] \\
\hline & & 12 & $\begin{array}{c}\text { Numerous website sections dedicated to } \\
\text { stakeholder-final consumer }\end{array}$ & By the authors \\
\hline & & 13 & $\begin{array}{c}\text { Numerous website sections dedicated to employee } \\
\text { involvement }\end{array}$ & Adapted from [5] \\
\hline & & 14 & $\begin{array}{l}\text { Numerous typical elements in section dedicated to } \\
\text { media relation }\end{array}$ & Adapted from [6] \\
\hline & \multirow{6}{*}{$\begin{array}{l}\text { Stakeholder } \\
\text { engagement tools }\end{array}$} & 15 & Materiality matrix & [6] \\
\hline & & 16 & Stakeholder engagement case study & {$[6]$} \\
\hline & & 17 & Community and forum & [6] \\
\hline & & 18 & Corporate blog & {$[6]$} \\
\hline & & 19 & Interactive graphs of sustainability & [6] \\
\hline & & 20 & Glossary and FAQ about sustainability & [6] \\
\hline & \multirow{2}{*}{$\begin{array}{c}\text { Governance of } \\
\text { sustainability: } \\
\text { organizational } \\
\text { model }\end{array}$} & 21 & $\begin{array}{l}\text { Strategic level: board of sustainability or CSR } \\
\text { committee, etc. }\end{array}$ & {$[6]$} \\
\hline & & 22 & $\begin{array}{l}\text { Operative level: sustainability or CSR Officer, CSR } \\
\text { team, etc. }\end{array}$ & [6] \\
\hline & \multirow{5}{*}{$\begin{array}{l}\text { Governance of } \\
\text { sustainability: } \\
\text { tools/resources of } \\
\text { corporate identity }\end{array}$} & 23 & Code of ethics & [6] \\
\hline & & 24 & Code of behavior or conduct & [6] \\
\hline & & 25 & Certifications (process and product) & [6] \\
\hline & & 26 & Sustainability index (Dow Jones) & Adapted from [6] \\
\hline & & 27 & Sustainability report & Adapted from [6] \\
\hline \multirow{17}{*}{ Ergonomics (27) } & \multirow{7}{*}{ Accessibility } & 28 & Compliance with W3C & [6] \\
\hline & & 29 & Multilingual functionality & [6] \\
\hline & & 30 & A link is availed and associated with sustainability & [81] \\
\hline & & 31 & Link is noticeable & [81] \\
\hline & & 32 & $\begin{array}{l}\text { web-based corp. sustainability comm. allocated } \\
\text { under "About Us" or "Investor Relations" }\end{array}$ & [81] \\
\hline & & 33 & Clearly labeled content indexes & [81] \\
\hline & & 34 & Home button setting accessibility & By the authors \\
\hline & \multirow{10}{*}{ Navigability } & 35 & Tools of navigation and search & [6] \\
\hline & & 36 & Search by default & [6] \\
\hline & & 37 & Direct access to information & {$[6]$} \\
\hline & & 38 & Page loading & {$[6]$} \\
\hline & & 39 & Website map & [6] \\
\hline & & 40 & Navigability with mobile & [6] \\
\hline & & 41 & Absence of link unreachable & [6] \\
\hline & & 42 & Clear structure & [81] \\
\hline & & 43 & Easy navigation & [81] \\
\hline & & 44 & Further information available & [81] \\
\hline
\end{tabular}


Table A1. Cont.

\begin{tabular}{|c|c|c|c|c|}
\hline Dimensions & Sub-Dimensions & $\mathbf{N}^{\mathbf{0}}$ & Items & Author Reference \\
\hline & & 45 & Absence of excessive horizontal or vertical scrolling & [6] \\
\hline & Usability & 46 & Absence of actions not required by the users & [6] \\
\hline & & 47 & Opportunity to go back and on homepage & [6] \\
\hline & & 48 & One-way interaction & [6] \\
\hline & Interactivity & 49 & Two-way (bidirectional) interaction & {$[6]$} \\
\hline & & 50 & Participation and co-creation & [6] \\
\hline & & 51 & Video & [6] \\
\hline & & 52 & Image & [6] \\
\hline & Multimedia & 53 & Magazine & {$[6]$} \\
\hline & & 54 & Web and interactive TV & Adapted from [6] \\
\hline \multirow{34}{*}{ Content (42) } & Initiatives of & 55 & Content related to core business & [6] \\
\hline & corporate & 56 & Content that impacts on the value chain & {$[6]$} \\
\hline & sustainability & 57 & Content of general social interest & [6] \\
\hline & \multirow{3}{*}{$\begin{array}{l}\text { Principle of } \\
\text { comm.: visibility }\end{array}$} & 58 & $\begin{array}{c}\text { Visibility of information about sustainability on the } \\
\text { homepage }\end{array}$ & [6] \\
\hline & & 59 & Visibility on search engines & [6] \\
\hline & & 60 & Orientation in sustainability section & [6] \\
\hline & \multirow{3}{*}{$\begin{array}{l}\text { Principle of } \\
\text { comm.: clarity }\end{array}$} & 61 & Clarity in classification of information & [6] \\
\hline & & 62 & Clarity in labelling system & [6] \\
\hline & & 63 & Clarity in graphs and diagrams & [6] \\
\hline & \multirow{3}{*}{$\begin{array}{l}\text { Principle of } \\
\text { comm.: } \\
\text { authenticity }\end{array}$} & 64 & Compliance of initiatives with corporate value & [6] \\
\hline & & 65 & Verifiability of information & [6] \\
\hline & & 66 & Case study, testimonials & [6] \\
\hline & \multirow{3}{*}{$\begin{array}{l}\text { Principle of } \\
\text { comm.: accuracy }\end{array}$} & 67 & Commitment in sustainability section & [6] \\
\hline & & 68 & Performance achieved in sustainability section & [6] \\
\hline & & 69 & Section of transparency & [6] \\
\hline & \multirow{3}{*}{$\begin{array}{l}\text { Principle of } \\
\text { comm.: } \\
\text { consistency }\end{array}$} & 70 & Persistence of corporate commitment & {$[6]$} \\
\hline & & 71 & $\begin{array}{l}\text { Consistency between image and text in sustainability } \\
\text { section }\end{array}$ & [6] \\
\hline & & 72 & $\begin{array}{l}\text { Consistency between orientation in section "About } \\
\text { Us" and sustainability section }\end{array}$ & [6] \\
\hline & \multirow{4}{*}{$\begin{array}{l}\text { Principle of } \\
\text { comm.: } \\
\text { completeness }\end{array}$} & 73 & Exhaustive sustainability section & [6] \\
\hline & & 74 & Contacts of the managers in sustainability & [6] \\
\hline & & 75 & Annual updating of sustainability report & [6] \\
\hline & & 76 & Weekly updating of news in website & {$[6]$} \\
\hline & \multirow{4}{*}{$\begin{array}{l}\text { General website } \\
\text { content }\end{array}$} & 77 & $\begin{array}{l}\text { Website appears engaging through use of multimedia } \\
\text { features }\end{array}$ & [81] \\
\hline & & 78 & Communicate through third parties & [81] \\
\hline & & 79 & Current commitment & [81] \\
\hline & & 80 & Consumer-oriented content and text & [81] \\
\hline & \multirow{4}{*}{$\begin{array}{l}\text { Industry-specific } \\
\text { sustainability } \\
\text { issues as content }\end{array}$} & 81 & Environmental issues & [81] \\
\hline & & 82 & Social issues & [81] \\
\hline & & 83 & Philanthropic issues & [81] \\
\hline & & 84 & Sustainable fashion traceability & [81] \\
\hline & \multirow{4}{*}{$\begin{array}{l}\text { Contact, feedback, } \\
\text { dialogue }\end{array}$} & 85 & Email or contact form for sustainability concerns & [81] \\
\hline & & 86 & Sustainability newsletter & [81] \\
\hline & & 87 & Frequent questionnaires/polls/Surveys & [81] \\
\hline & & 88 & Online Forum / online community & [81] \\
\hline
\end{tabular}


Table A1. Cont.

\begin{tabular}{|c|c|c|c|c|}
\hline Dimensions & Sub-Dimensions & $\mathbf{N}^{\circ}$ & Items & Author Reference \\
\hline & \multirow{6}{*}{$\begin{array}{c}\text { Sustainable } \\
\text { development } \\
\text { agenda }\end{array}$} & 89 & Interaction & [81] \\
\hline & & 90 & Partnership & [81] \\
\hline & & 91 & Local sustainability developments & {$[81]$} \\
\hline & & 92 & Global sustainability developments & [81] \\
\hline & & 93 & Objectives for sustainability development & [81] \\
\hline & & 94 & Membership(s) in sustainability initiatives & [81] \\
\hline & \multirow{2}{*}{$\begin{array}{l}\text { Consumer } \\
\text { involvement }\end{array}$} & 95 & $\begin{array}{c}\text { Visibility of information on product origin and } \\
\text { traceability }\end{array}$ & By the authors \\
\hline & & 96 & $\begin{array}{l}\text { Visibility of information about the clothing end of life } \\
\text { process }\end{array}$ & Adapted from [32] \\
\hline
\end{tabular}

Table A2. Operational Model for Evaluating Fashion E-Commerce (OMEFeC-OSEC).

\begin{tabular}{|c|c|c|c|c|}
\hline Dimensions & Sub-Dimensions & $\mathbf{N}^{\mathbf{o}}$ & Items & Author Reference \\
\hline \multirow{9}{*}{ Orientation (9) } & \multirow{3}{*}{ About us } & 1 & Explicit references to sustainability & [6] \\
\hline & & 2 & Explicit references to environmental sustainability & [6] \\
\hline & & 3 & Explicit references to people (sustainability) & Adapted from [6] \\
\hline & \multirow{6}{*}{$\begin{array}{c}\text { Sustainability } \\
\text { web } \\
\text { section/microsite }\end{array}$} & 4 & Explicit references to sustainability & [6] \\
\hline & & 5 & Explicit references to environmental sustainability & [6] \\
\hline & & 6 & Explicit references to people (sustainability) & Adapted from [6] \\
\hline & & 7 & Sustainability strategy & [81] \\
\hline & & 8 & Top management commitment & [81] \\
\hline & & 9 & Most important sustainability challenges mentioned & [81] \\
\hline \multirow{15}{*}{ Structure (15) } & \multirow{8}{*}{$\begin{array}{c}\text { Stakeholder } \\
\text { engagement tool }\end{array}$} & 10 & $\begin{array}{c}\text { Numerous website sections dedicated to } \\
\text { stakeholder-final consumer }\end{array}$ & By the authors \\
\hline & & 11 & $\begin{array}{l}\text { Numerous typical elements in section dedicated to } \\
\text { media relation }\end{array}$ & [6] \\
\hline & & 12 & Materiality matrix & [6] \\
\hline & & 13 & Stakeholder engagement case study & [6] \\
\hline & & 14 & Community and forum & {$[6]$} \\
\hline & & 15 & Corporate blog & [6] \\
\hline & & 16 & Interactive graphs of sustainability & {$[6]$} \\
\hline & & 17 & Glossary and FAQ about sustainability & [6] \\
\hline & \multirow{2}{*}{$\begin{array}{c}\text { Governance of } \\
\text { sustainability: } \\
\text { organizational } \\
\text { model }\end{array}$} & 18 & $\begin{array}{l}\text { Strategic level: board of sustainability or CSR } \\
\text { committee, etc. }\end{array}$ & [6] \\
\hline & & 19 & $\begin{array}{l}\text { Operative level: sustainability or CSR Officer, CSR } \\
\text { team, etc. }\end{array}$ & [6] \\
\hline & \multirow{5}{*}{$\begin{array}{l}\text { Governance of } \\
\text { sustainability: } \\
\text { tools/resources of } \\
\text { corporate identity }\end{array}$} & 20 & Code of ethics & [6] \\
\hline & & 21 & Code of behavior or conduct & [6] \\
\hline & & 22 & Certifications (process and product) & [6] \\
\hline & & 23 & Sustainability Index (Dow Jones) & [6] \\
\hline & & 24 & Sustainability report & [6] \\
\hline
\end{tabular}


Table A2. Cont.

\begin{tabular}{|c|c|c|c|c|}
\hline Dimensions & Sub-Dimensions & $\mathbf{N}^{\mathbf{0}}$ & Items & Author Reference \\
\hline \multirow{27}{*}{ Ergonomics (27) } & \multirow{7}{*}{ Accessibility } & 25 & Compliance with W3C & [6] \\
\hline & & 26 & Multilingual functionality & [6] \\
\hline & & 27 & A link is available and associated with sustainability & [81] \\
\hline & & 28 & Link is noticeable & [81] \\
\hline & & 29 & $\begin{array}{l}\text { Web-based corp. sustainability comm. allocated } \\
\text { under "About Us" or "Investor Relations" }\end{array}$ & [81] \\
\hline & & 30 & Clearly labeled content indexes & [81] \\
\hline & & 31 & Home button settings accessibility & By the authors \\
\hline & \multirow{10}{*}{ Navigability } & 32 & Tools of navigation and search & [6] \\
\hline & & 33 & Search by default & [6] \\
\hline & & 34 & Direct access to information & {$[6]$} \\
\hline & & 35 & Page loading & [6] \\
\hline & & 36 & Website map & [6] \\
\hline & & 37 & Navigability with mobile & [6] \\
\hline & & 38 & Absence of link unreachable & [6] \\
\hline & & 39 & Clear structure & [81] \\
\hline & & 40 & Easy navigation & [81] \\
\hline & & 41 & Further information available & [81] \\
\hline & \multirow{3}{*}{ Usability } & 42 & Absence of excessive horizontal or vertical scrolling & [6] \\
\hline & & 43 & Absence of actions not required by the users & [6] \\
\hline & & 44 & Opportunity to go back and on homepage & {$[6]$} \\
\hline & \multirow{3}{*}{ Interactivity } & 45 & One-way interaction & [6] \\
\hline & & 46 & Two-way (bidirectional) interaction & [6] \\
\hline & & 47 & Participation and co-creation & [6] \\
\hline & \multirow{4}{*}{ Multimedia } & 48 & Video & [6] \\
\hline & & 49 & Image & [6] \\
\hline & & 50 & Magazine & [6] \\
\hline & & 51 & Web and interactive TV & [6] \\
\hline \multirow{22}{*}{$\begin{array}{l}\text { Content } \\
\quad(48)\end{array}$} & \multirow{3}{*}{$\begin{array}{l}\text { Initiatives of } \\
\text { corporate } \\
\text { sustainability }\end{array}$} & 52 & Content related to core business & [6] \\
\hline & & 53 & Content that impacts on the value chain & [6] \\
\hline & & 54 & Content of general social interest & {$[6]$} \\
\hline & \multirow{3}{*}{$\begin{array}{l}\text { Principle of } \\
\text { comm.: visibility }\end{array}$} & 55 & $\begin{array}{c}\text { Visibility of information about sustainability on the } \\
\text { homepage }\end{array}$ & [6] \\
\hline & & 56 & Visibility on search engines & [6] \\
\hline & & 57 & Orientation in sustainability section & [6] \\
\hline & \multirow{3}{*}{$\begin{array}{l}\text { Principle of } \\
\text { comm.: clarity }\end{array}$} & 58 & Clarity in classification of information & [6] \\
\hline & & 59 & Clarity in labeling system & [6] \\
\hline & & 60 & Clarity in graphs and diagrams & [6] \\
\hline & \multirow{3}{*}{$\begin{array}{l}\text { Principle of } \\
\text { comm.: } \\
\text { authenticity }\end{array}$} & 61 & Compliance of initiatives with corporate value & {$[6]$} \\
\hline & & 62 & Verifiability of information & {$[6]$} \\
\hline & & 63 & Case study, testimonials & [6] \\
\hline & \multirow{3}{*}{$\begin{array}{l}\text { Principle of } \\
\text { comm.: accuracy }\end{array}$} & 64 & Commitment in sustainability section & [6] \\
\hline & & 65 & Performance achieved in sustainability section & [6] \\
\hline & & 66 & Section of transparency & [6] \\
\hline & \multirow{3}{*}{$\begin{array}{l}\text { Principle of } \\
\text { comm.: } \\
\text { consistency }\end{array}$} & 67 & Persistence of corporate commitment & {$[6]$} \\
\hline & & 68 & $\begin{array}{l}\text { Consistency between image and text in sustainability } \\
\text { section }\end{array}$ & {$[6]$} \\
\hline & & 69 & $\begin{array}{l}\text { Consistency between orientation in section "About } \\
\text { Us" and sustainability section }\end{array}$ & [6] \\
\hline & \multirow{4}{*}{$\begin{array}{l}\text { Principle of } \\
\text { comm.: } \\
\text { completeness }\end{array}$} & 70 & Exhaustive sustainability section & [6] \\
\hline & & 71 & Contacts of the managers in sustainability & [6] \\
\hline & & 72 & Annual updating of sustainability report & [6] \\
\hline & & 73 & Weekly updating of news in website & {$[6]$} \\
\hline
\end{tabular}


Table A2. Cont.

\begin{tabular}{|c|c|c|c|c|}
\hline Dimensions & Sub-Dimensions & $\mathrm{N}^{\mathbf{o}}$ & Items & Author Reference \\
\hline & \multirow{4}{*}{$\begin{array}{l}\text { General website } \\
\text { content }\end{array}$} & 74 & $\begin{array}{l}\text { Website appears engaging through use of multimedia } \\
\text { features }\end{array}$ & [81] \\
\hline & & 75 & Communicate through third parties & [81] \\
\hline & & 76 & Current commitment & [81] \\
\hline & & 77 & Consumer-oriented content and text & [81] \\
\hline & \multirow{4}{*}{$\begin{array}{l}\text { Industry-specific } \\
\text { sustainability } \\
\text { issues as content }\end{array}$} & 78 & Environmental issues & [81] \\
\hline & & 79 & Social issues & [81] \\
\hline & & 80 & Philanthropic issues & [81] \\
\hline & & 81 & Sustainable fashion collection & [81] \\
\hline & \multirow{4}{*}{$\begin{array}{l}\text { Contact, feedback, } \\
\text { dialogue }\end{array}$} & 82 & Email or contact form for sustainability concerns & [81] \\
\hline & & 83 & Sustainability newsletter & [81] \\
\hline & & 84 & Frequent questionnaires/polls/surveys & [81] \\
\hline & & 85 & Online Forum / online community & [81] \\
\hline & \multirow{6}{*}{$\begin{array}{c}\text { Sustainable } \\
\text { development } \\
\text { agenda }\end{array}$} & 86 & Interaction & [81] \\
\hline & & 87 & Partnership & [81] \\
\hline & & 88 & Local sustainability developments & [81] \\
\hline & & 89 & Global sustainability developments & [81] \\
\hline & & 90 & Objectives for sustainability development & [81] \\
\hline & & 91 & Membership(s) in sustainability initiatives & [81] \\
\hline & \multirow{4}{*}{$\begin{array}{l}\text { In sustainability } \\
\text { section }\end{array}$} & 92 & $\begin{array}{c}\text { Visibility of information on product origin and } \\
\text { traceability }\end{array}$ & By the authors \\
\hline & & 93 & Visibility of clothing care information (usage phase) & Adapted from [32] \\
\hline & & 94 & $\begin{array}{l}\text { Visibility of information about the clothing recycling } \\
\text { process (recycling) }\end{array}$ & Adapted from [32] \\
\hline & & 95 & $\begin{array}{l}\text { Visibility of information about sustainable } \\
\text { consumption }\end{array}$ & Adapted from [32] \\
\hline & \multirow{4}{*}{$\begin{array}{l}\text { In products } \\
\text { technical sheet }\end{array}$} & 96 & $\begin{array}{c}\text { Visibility of information on product origin and } \\
\text { traceability }\end{array}$ & By the authors \\
\hline & & 97 & Visibility of clothing care information (usage phase) & By the authors \\
\hline & & 98 & $\begin{array}{c}\text { Visibility of information about the clothing end of life } \\
\text { process (recycling) }\end{array}$ & By the authors \\
\hline & & 99 & $\begin{array}{c}\text { Visibility of information about sustainable } \\
\text { consumption }\end{array}$ & [81] \\
\hline
\end{tabular}

\section{References}

1. Olofsson, L.; Mark-Herbert, C. Creating Shared Values by Integrating Un Sustainable Development Goals in Corporate Communication-the Case of Apparel Retail. Sustainability 2020, 12, 8806. [CrossRef]

2. Yang, S.; Song, Y.; Tong, S. Sustainable Retailing in the Fashion Industry: A Systematic Literature Review. Sustainability 2017, 9, 1266. [CrossRef]

3. Du, S.; Bhattacharya, C.B.; Sen, S. Maximizing Business Returns to Corporate Social Responsibility (CSR): The Role of CSR Communication. Int. J. Manag. Rev. 2010, 12, 8-19. [CrossRef]

4. Morsing, M.; Schultz, M. Corporate Social Responsibility Communication: Stakeholder Information, Response and Involvement Strategies. Bus. Ethics A Eur. Rev. 2006, 15, 323-338. [CrossRef]

5. Ott, H.; Wang, R.; Bortree, D. Communicating Sustainability Online: An Examination of Corporate, Nonprofit, and University Websites. Mass. Commun. Soc. 2016, 19, 671-687. [CrossRef]

6. Siano, A.; Conte, F.; Amabile, S.; Vollero, A.; Piciocchi, P. Communicating Sustainability: An Operational Model for Evaluating Corporate Websites. Sustainability 2016, 8, 950. [CrossRef]

7. Baldassarre, F.; Campo, R. Sustainability as a Marketing Tool: To Be or to Appear to Be? Bus. Horiz. 2016, 59, 421-429. [CrossRef]

8. Kusá, A.; Urmínová, M. Communication as a Part of Identity of Sustainable Subjects in Fashion. J. Risk Financ. Manag. 2020, 13, 305. [CrossRef]

9. Pomering, A.; Dolnicar, S. Assessing the Prerequisite of Successful CSR Implementation: Are Consumers Aware of CSR Initiatives? J. Bus. Ethics 2009, 85, 285-301. [CrossRef]

10. Rodríguez Salinas, C.; Albertini, N.; Ferrazza, L. LA Perse by Cristobal Balenciaga: An Historical, Scientific and Conservation Study. Fash. Theory 2021, 25, 541-561. [CrossRef] 
11. Casadei, P.; Lee, N. Global Cities, Creative Industries and Their Representation on Social Media: A Micro-Data Analysis of Twitter Data on the Fashion Industry. Environ. Plan. A Econ. Sp. 2020, 52, 1195-1220. [CrossRef]

12. Greffe, X. Managing Creative Enterprises. Creative Industries, Creative Industries Booklet No. 3. Geneva: World Intellectual Property Organization. 2006. Available online: http:/ / www.wipo.int (accessed on 27 May 2021).

13. Díaz-Soloaga, P. The Role of Communication in Organizational Culture. Is There a Pattern in Spanish Fashion Companies? Prof. Inf. 2019, 28, e280506. [CrossRef]

14. Vadillo, M. El Triunfo de Los Diseñadores Invisibles: La Bauhaus En Femenino. I+ Diseño Rev. Int. Investig. Innovación Desarro Diseño 2009, 1, 27-34.

15. European Commission. The European Green Deal; European Commission: Brussels, Belgium, 2019.

16. Von der Leyen, U. Opening Address: Europe in a Changing World; European Commission: Brussels, Belgium, 2021.

17. United Nations. Alliance for Sustainable Fashion; United Nations: Nairobi, Kenya, 2019.

18. Statista. Apparel Market Worldwide; Statista: Hamburg, Germany, 2021.

19. Ley, K.; van Mazijk, R.; Boger, S. Financing the Transformation in the Fashion Industry. Unlocking Investment to Scale Innovation; Fashion for Good and Boston Consulting Group: Amsterdam, The Netherlands; Boston, MA, USA, 2020; Available online: https: //fashionforgood.com/wp-content/uploads/2020/01/FinancingTheTransformation_Report_FINAL_Digital-1.pdf (accessed on 22 July 2021).

20. MacArthur, F.E. A New Textiles Economy: Redesigning Fashion's Future; Ellen MacArthur Foundation: Cowes, UK, 2017; pp. 1-150.

21. International Labour Organization. Wages and Working Hours in the Textiles, Clothing, Leather and Footwear Industries; International Labour Organization: Geneva, Switzerland, 2014.

22. Luján-Ornelas, C.; Güereca, L.P.; Franco-García, M.-L.; Heldeweg, M. A Life Cycle Thinking Approach to Analyse Sustainability in the Textile Industry: A Literature Review. Sustainability 2020, 12, 193. [CrossRef]

23. The Business of Fashion. The State of Fashion 2021; The Business of Fashion: London, UK, 2021.

24. Brundtland, G.H. Report of the World Commission on Environment and Development; Our Common Future, Bruntland Report; New York UN Doc.; Oxford University Press: Oxford, UK, 1987.

25. Elkington, J. Accounting for the triplle bottom line. Meas. Bus. Excell. 1998, 2, 18-22. [CrossRef]

26. Arici, G.; Lehmann, M. CEO Agenda 2020_Covid 19 Edition; Global Fashion Agenda \& McKinsey: Copenhagen, Denmark, 2021.

27. Deheinzelin, L. Economía Creativa, Sostenibilidad y Su Relacion de Futuros Deseables. Rev. Mex. Bachill. Distancia 2011, 3. [CrossRef]

28. Garcia-Torres, S.; Rey-Garcia, M.; Albareda-Vivo, L. Effective Disclosure in the Fast-Fashion Industry: From Sustainability Reporting to Action. Sustainability 2017, 9, 2256. [CrossRef]

29. United Nations. United Nations Climate Change. Helps Fashion Industry Shift to Low Carbon. September 6, 2018; United Nations: San Francisco, CA, USA, 2018.

30. Preferred Fiber and Materials Report. Textile Exchange. 2020. Available online: https://textileexchange.org/2020-preferredfiber-and-materials-market-report-pfmr-released-2/ (accessed on 29 June 2020).

31. Shirvanimoghaddam, K.; Motamed, B.; Ramakrishna, S.; Naebe, M. Death by Waste: Fashion and Textile Circular Economy Case. Sci. Total Environ. 2020, 718, 137317. [CrossRef]

32. Strähle, J.; Will, C.; Freise, M. Communication of Sustainability At European Fashion Online Shops. Int. J. Econ. Commer. Manag. 2015, III, 71-86.

33. Choudhary, M.; Seth, N. Integration of Green Practices in Supply Chain Environment the Practices of Inbound, Operational, Outbound and Reverse Logistics. Int. J. Eng. Sci. Technol. 2011, 3, 4985-4993.

34. Connell, K.Y.H. Internal and External Barriers to Eco-Conscious Apparel Acquisition. Int. J. Consum. Stud. 2010, 34, $279-286$. [CrossRef]

35. Hill, J.; Lee, H. Young Generation Y Consumers' Perceptions of Sustainability in the Apparel Industry. J. Fash. Mark. Manag. Int. J. 2012, 16, 477-491. [CrossRef]

36. D'Souza, C.; Taghian, M.; Lamb, P. An Empirical Study on the Influence of Environmental Labels on Consumers. Corp. Commun. Int. J. 2006, 11, 162-173. [CrossRef]

37. Blasi, S.; Brigato, L.; Sedita, S.R. Eco-Friendliness and Fashion Perceptual Attributes of Fashion Brands: An Analysis of Consumers' Perceptions Based on Twitter Data Mining. J. Clean. Prod. 2020, 244, 118701. [CrossRef]

38. Kong, H.M.; Witmaier, A.; Ko, E. Sustainability and Social Media Communication: How Consumers Respond to Marketing Efforts of Luxury and Non-Luxury Fashion Brands. J. Bus. Res. 2021, 131, 640-651. [CrossRef]

39. Pencarelli, T.; Taha, V.A.; Škerháková, V.; Valentiny, T.; Fedorko, R. Luxury Products and Sustainability Issues from the Perspective of Young Italian Consumers. Sustainability 2020, 12, 245. [CrossRef]

40. Caro, F.; Martínez-de-Albéniz, V. Fast Fashion: Business Model Overview and Research Opportunities. In Retail Supply Chain Management; Springer: Berlin/Heidelberg, Germany, 2015; pp. 237-264.

41. Davies, I.A.; Lee, Z.; Ahonkhai, I. Do Consumers Care About Ethical-Luxury? J. Bus. Ethics 2012, 106, 37-51. [CrossRef]

42. Arrigo, E. Innovation and Market-Driven Management in Fast Fashion Companies. Symph. Emerg. Issues Manag. 2010,2 , 67-85. [CrossRef]

43. Yoon, N.; Lee, H.K.; Choo, H.J. Fast Fashion Avoidance Beliefs and Anti-Consumption Behaviors: The Cases of Korea and Spain. Sustainability 2020, 12, 6907. [CrossRef] 
44. Hidayati, S.C.; Hua, K.-L.; Cheng, W.-H.; Sun, S.-W. What Are the Fashion Trends in New York? In Proceedings of the 22nd ACM International Conference on Multimedia, Orlando, FL, USA, 3-7 November 2014; pp. 197-200.

45. Fletcher, K. Slow Fashion: An Invitation for Systems Change. Fash. Pract. 2010, 2, 259-265. [CrossRef]

46. Henninger, C.E.; Alevizou, P.J.; Oates, C.J. What Is Sustainable Fashion? J. Fash. Mark. Manag. Int. J. 2016, 20, 400-416. [CrossRef]

47. Achabou, M.A.; Dekhili, S. Luxury and Sustainable Development: Is There a Match? J. Bus. Res. 2013, 66, 1896-1903. [CrossRef]

48. Joy, A.; Sherry, J.F.; Venkatesh, A.; Wang, J.; Chan, R. Fast Fashion, Sustainability, and the Ethical Appeal of Luxury Brands. Fash. Theory J. Dress Body Cult. 2012, 16, 273-295. [CrossRef]

49. Islam, M.D.N.; Ozuem, W.; Bowen, G.; Willis, M.; Ng, R. An Empirical Investigation and Conceptual Model of Perceptions, Support, and Barriers to Marketing in Social Enterprises in Bangladesh. Sustainability 2021, 13, 345. [CrossRef]

50. Rotimi, E.O.O.; Topple, C.; Hopkins, J. Towards A Conceptual Framework of Sustainable Practices of Post-Consumer Textile Waste at Garment End of Lifecycle: A Systematic Literature Review Approach. Sustainability 2021, 13, 2965. [CrossRef]

51. Karell, E.; Niinimäki, K. Addressing the Dialogue between Design, Sorting and Recycling in a Circular Economy. Des. J. 2019, 22 (Suppl. 1), 997-1013. [CrossRef]

52. Blazquez, M.; Henninger, C.E.; Alexander, B.; Franquesa, C. Consumers' Knowledge and Intentions towards Sustainability: A Spanish Fashion Perspective. Fash. Pract. 2020, 12, 34-54. [CrossRef]

53. Karaosman, H.; Perry, P.; Brun, A.; Morales-Alonso, G. Behind the Runway: Extending Sustainability in Luxury Fashion Supply Chains. J. Bus. Res. 2020, 117, 652-663. [CrossRef]

54. Kent, T. 2D23D: Management and Design Perspectives on Retail Branding. Int. J. Retail Distrib. Manag. 2003, 31, 131-142. [CrossRef]

55. Pérez-Bou, S.; Valerio, M.; Eugui, P. Fashion Stores as potential educators of conscious consumers. 2 case studies: H\&M Group and Inditex. In Proceedings of the 20th European Roundtable Sustainable Consumption and Production, Graz, Austria, 8-10 September 2021.

56. Finne, Å.; Grönroos, C. Communication-in-Use: Customer-Integrated Marketing Communication. Eur. J. Mark. 2017, 51, 445-463. [CrossRef]

57. Park, G.; Park, H.S. Communicating Sustainability to Ethnocentric Consumers in China: Focusing on Social Distance from Foreign Corporations. Sustainability 2021, 13, 47. [CrossRef]

58. Signitzer, B.; Prexl, A. Corporate Sustainability Communications: Aspects of Theory and Professionalization. J. Public Relat. Res. 2007, 20, 1-19. [CrossRef]

59. Da Giau, A.; Macchion, L.; Caniato, F.; Caridi, M.; Danese, P.; Rinaldi, R.; Vinelli, A. Sustainability Practices and Web-Based Communication: An Analysis of the Italian Fashion Industry. J. Fash. Mark. Manag. 2016, 20, 72-88. [CrossRef]

60. Wheeler, D.; Elkington, J. The End of the Corporate Environmental Report? Or the Advent of Cybernetic Sustainability Reporting and Communication. Bus. Strateg. Environ. 2001, 10, 1-14. [CrossRef]

61. Islas, O. Internet 2.0: El Territorio Digital de Los Prosumidores. Rev. Estud. Cult. 2010, 3, 43-63.

62. Kotler, P.; Kartajaya, H.; Setiawan, I. Marketing 4.0: Moving from Traditional to Digital; John Wiley \& Sons, Inc.: Hoboken, NJ, USA, 2017.

63. Morgan-Thomas, A.; Veloutsou, C. Beyond Technology Acceptance: Brand Relationships and Online Brand Experience. J. Bus. Res. 2013, 66, 21-27. [CrossRef]

64. Busca, L.; Bertrandias, L. A Framework for Digital Marketing Research: Investigating the Four Cultural Eras of Digital Marketing. J. Interact. Mark. 2020, 49, 1-19. [CrossRef]

65. Castells, M. La Era de La Información: Economía, Sociedad y Cultura; Siglo XXI: Madrid, Spain, 2001; Volume 3.

66. Gong, W.; Li, Z.G.; Stump, R.L. Global Internet Use and Access: Cultural Considerations. Asia Pac. J. Mark. Logist. 2007, 19, 57-74. [CrossRef]

67. Noris, A.; SanMiguel, P.; Cantoni, L. Localization and Cultural Adaptation on the Web: An Explorative Study in the Fashion Domain. In International Conference on Human-Computer Interaction; Springer: Berlin/Heidelberg, Germany, 2020 ; pp. 474-492.

68. Ngarmwongnoi, C.; Oliveira, J.S.; AbedRabbo, M.; Mousavi, S. The Implications of EWOM Adoption on the Customer Journey. J. Consum. Mark. 2020, 37, 749-759. [CrossRef]

69. Testa, D.S.; Bakhshian, S.; Eike, R. Engaging Consumers with Sustainable Fashion on Instagram. J. Fash. Mark. Manag. Int. J. 2021. Ahead of print. [CrossRef]

70. Sádaba, T.; SanMiguel, P.; Gargoles, P. Communication Crisis in Fashion: From the Rana Plaza Tragedy to the Bravo Tekstil Factory Crisis; Springer: Cham, Switzerland, 2019. [CrossRef]

71. Noris, A.; Nobile, T.H.; Kalbaska, N.; Cantoni, L. Digital Fashion: A Systematic Literature Review. A Perspective on Marketing and Communication. J. Glob. Fash. Mark. 2020, 12, 32-46. [CrossRef]

72. Yadav, M.S.; de Valck, K.; Hennig-Thurau, T.; Hoffman, D.L.; Spann, M. Social Commerce: A Contingency Framework for Assessing Marketing Potential. Soc. Media Mark. 2013, 27, 311-323. [CrossRef]

73. Dahl, R. Green Washing: Do You Know What You're Buying? Natl. Inst. Environ. Health Sci. 2010. [CrossRef] [PubMed]

74. Delmas, M.A.; Burbano, V.C. The Drivers of Greenwashing. Calif. Manag. Rev. 2011, 54, 64-87. [CrossRef]

75. Szabo, S.; Webster, J. Perceived Greenwashing: The Effects of Green Marketing on Environmental and Product Perceptions. J. Bus. Ethics 2020, 171, 1-21. [CrossRef]

76. Macgregor, R.K.; Sroka, W.; Macgregor Pelikánová, R. A Comparative Study of Low-Level Management's Attitude to Marketing and Innovations in the Luxury Fashion Industry: Pro-or Anti-CSR? Pol. J. Manag. Stud. 2020, 21, 240-255. [CrossRef] 
77. Nosratabadi, S.; Mosavi, A.; Shamshirband, S.; Zavadskas, E.K.; Rakotonirainy, A.; Chau, K.W. Sustainable Business Models: A Review. Sustainability 2019, 11, 1663. [CrossRef]

78. Fulton, K.; Lee, S.E. Assessing Sustainable Initiatives of Apparel Retailers on the Internet. J. Fash. Mark. Manag. 2013, 17, 353-366. [CrossRef]

79. MacGregor, R.K.; Sroka, W.; Pelikánová, R.M.G. The CSR Perception of Front-Line Employees of Luxury Fashion Businesses. Organizacija 2020, 53, 198-211. [CrossRef]

80. Porter, M.E.; Kramer, M.R. The Link between Competitive Advantage and Corporate Social Responsibility. Harv. Bus. Rev. 2006, 84, 78-92.

81. Dach, L.; Allmendinger, K. Sustainability in Corporate Communications and Its Influence on Consumer Awareness and Perceptions: A Study of H\&M and Primark. Procedia Soc. Behav. Sci. 2014, 130, 409-418. [CrossRef]

82. Reilly, A.H.; Hynan, K.A. Corporate Communication, Sustainability, and Social Media: It's Not Easy (Really) Being Green. Bus. Horiz. 2014, 57, 747-758. [CrossRef]

83. Kim, Y.; Oh, K.W. Which Consumer Associations Can Build a Sustainable Fashion Brand Image? Evidence from Fast Fashion Brands. Sustainability 2020, 12, 1703. [CrossRef]

84. Du, S.; Bhattacharya, C.B.; Sen, S. Reaping Relational Rewards from Corporate Social Responsibility: The Role of Competitive Positioning. Int. J. Res. Mark. 2007, 24, 224-241. [CrossRef]

85. Sheth, J.N. Impact of Emerging Markets on Marketing: Rethinking Existing Perspectives and Practices. J. Mark. 2011, 75, 166-182 [CrossRef]

86. Moorhouse, D.; Moorhouse, D. Sustainable Design: Circular Economy in Fashion and Textiles. Des. J. 2017, 20 (Suppl. 1), S1948-S1959. [CrossRef]

87. Godemann, J.; Michelsen, G. Sustainability Communication Interdisciplinary Perspectives and Theoretical Foundations; Springer Science \& Business Media: Berlin/Heidelberg, Germany, 2011.

88. Grazzini, L.; Acuti, D.; Aiello, G. Solving the Puzzle of Sustainable Fashion Consumption: The Role of Consumers' Implicit Attitudes and Perceived Warmth. J. Clean. Prod. 2021, 287, 125579. [CrossRef]

89. Lim, W.M. Inside the Sustainable Consumption Theoretical Toolbox: Critical Concepts for Sustainability, Consumption, and Marketing. J. Bus. Res. 2017, 78, 69-80. [CrossRef]

90. Lim, W.M. A Blueprint for Sustainability Marketing: Defining Its Conceptual Boundaries for Progress. Mark. Theory 2016, 16, 232-249. [CrossRef]

91. Smith, K. LVMH Dismisses Kering's Sustainability Pact. Available online: https://fashionista.com/2019/09/lvmh-dismisseskering-sustainbility-pact (accessed on 22 July 2021).

92. Inditex. Annual Report 2019; Inditex: La Coruña, Spain, 2020; Available online: https://www.inditex.com/documents/10279/64 5708/Memoria+Anual+Inditex+2019.pdf/27465242-da48-b63a-a5f9-9afca6032cf0 (accessed on 22 July 2021). 